\title{
Constitutional Challenges to Gerrymanders
}

Reapportionment litigation falls into two broad classes. Within the first class are those challenges to districting schemes that allege violations of the one person, one vote mandate of Reynolds $v$. Sims. ${ }^{1}$ These cases ${ }^{2}$ involve a relatively straightforward inquiry into the population disparities among a state's election districts: the issue is whether district-to-district variations lie within permissible limits. Such cases are appropriately designated as "quantitative" reapportionment cases. ${ }^{3}$ More complex, and not yet judicially settled, is the second class of cases: challenges to gerrymanders based upon a broad interpretation of Reynolds's command that all voters must have an "equally effective voice"4 in the election of their representatives. These "qualitative" claims are founded on the recognition that equality of voting district populations does not guarantee "substantive equality in the sharing of power."s

The gerrymander may be defined as a division of electoral districts that maximizes the voting strength of one political party or faction. Three types of gerrymander may give rise to qualitative districting challenges: (1) splitting a hostile voting group among

377 U.S. 533 (1964).

2 See, e.g., Gaffney v. Cummings, 412 U.S. 735, 740-51 (1953); Mahan v. Howell, 410 U.S. 315 (1973); Swann v. Adams, 385 U.S. 440 (1967).

3 Nevett v. Sides, 571 F.2d 209, 215 (5th Cir. 1978). The Supreme Court has stated that the basis for challenges to such numerical disparity among voting districts lies in the "dilution" of the strength of the individual's vote. Gomillion v. Lightfoot, 364 U.S. 339, 346 (1960) (discussing Colegrove v. Green, 328 U.S. 549 (1946)).

+ 377 U.S. at 565.

- Casper, Social Differences and the Franchise, 105 Dakdalus 103, 112 (1976); see Neal, Baker v. Carr: Politics in Search of Law, 1976 Sup. Cr. Rev. 252, 278.

- Judge, now Justice, Stevens adopted the following definition of "gerrymander": "an unfair arrangement of electoral districts designed by the dominant party to give it an advantage over its rival in future elections." Cousins v. City Council, 466 F.2d 830, 847 (7th Cir.), cert. denied, 409 U.S. 893 (1972) (Stevens, Cir. J., dissenting). See L. TrIBE, Amarican Constitutional Law \& 13-9, 756 n.1 (1978). This comment will adopt a somewhat broader definition: gerrymandering is districting with discriminatory effects that result not only from a legislative intent, but may result from any facially neutral districting plan. See $R$. Drxon, Democratic Representation: Reapportionment in Lap and Politics 461-63 (1968). The use of districting itself has been demonstrated to create a bias in favor of the dominant political party. Id. at 462. The possibility of "underrepresentation" of voting factions exists to a lesser extent under systems of proportional representation, such as those of the Netherlands and Israel. See D. Rae, The Polmtical Consequences or Election Laws 28-39, 87-103 (1967). Within the scope of the term "gerrymander" lie both constitutionally "fair" and "unfair" districting schemes. See Gaffney v. Cummings, 412 U.S. 735 (1973) (gerrymander designed to apportion legislative seats fairly between political parties). 
several districts so that it constitutes a minority in each, ${ }^{7}(2)$ concentrating a voting bloc into one district of nearly unanimous opinion, ${ }^{8}$ and (3) creating multimember districts ${ }^{9}$ or providing for atlarge election of representatives. ${ }^{10}$ Each of these forms of gerrymandering has the effect of "diluting" the political power of a minority voting group. By eliminating the minority group's influence in the political system or by minimizing the number of districts the minority group controls, these gerrymanders effectively debase the individual vote of each member of the group."

Until recently, gerrymanders were immune from challenge in the courts even though they had been attacked for elevating the interests and opinions of some voters over those of others. ${ }^{12}$ In 1962 in Baker $v$. Carr, ${ }^{13}$ the Supreme Court rejected the view that apportionment controversies are beyond judicial scrutiny. Lower courts have, however, continued to hold certain types of gerrymander claims nonjusticiable. ${ }^{14}$ The challenges to gerrymandering that have

'See, e.g., Kirksey v. Board of Supervisors, 554 F.2d 139 (5th Cir.) (en banc), cert. denied, 434 U.S. 968 (1977).

8 See, e.g., Wright v. Rockefeller, 376 U.S. 52 (1964). Such districting "wastes" the votes of the supramajority.

' See, e.g., White v. Regester, 412 U.S. 755 (1973).

10 Nevett v. Sides, 571 F.2d 209, 216 (5th Cir. 1978); Bolden v. City of Mobile, 571 F.2d 238 (5th Cir.), prob. juris. noted, 47 U.S.L.W. 3221 (U.S. Oct. 2, 1978) (No. 77-1844). Multimember and at-large districting plans cancel out the "natural effect" of a cohesive residency pattern of a voting bloc. Nevett, 571 F.2d at 216.

"See R. Dixon, supra note 6, at 462-63. In the wake of the Supreme Court's "one man, one vote" pronouncement in Reynolds v. Sims, 377 U.S. 533 (1964), which foreclosed numerical malapportioniment as a means of rigging the balance of political power, the gerrymander has become state legislatures' primary vehicle for protecting the political power of the controlling party. Moreover, commentators have noted that the mandate of equally weighted votes has had the inadvertent effect of significantly increasing the use of gerrymanders to manipulate the electoral process. See, e.g., Clinton, Further Exploration in the Political Thicket: The Gerrymander and the Constitution, 59 Iowa L. REv. 1, 4 (1973); Elliot, Prometheus, Proteus, Pandora, and Procrustes Unbound: The Political Consequences of Reapportionment, 37 U. CHI. L. REv. 474, 483 (1970).

12 This immunity reflected the long-standing view that the drawing of election boundaries and the apportionment of representatives were political questions constitutionally committed to the state legislatures; allowing only for limited oversight by Congress in the case of federal elections. See Colegrove v. Green, 328 U.S. 549, 554 (1946) (plurality opinion). It was thought unseemly and intrusive for judges to venture into the."political thicket", id. at 556, and, in effect, to adjudicate particular election outcomes. In general, the evils of gerrymanders were preferred to the expansive judicial role required for their remedy. As Justice Rutledge noted in Colegrove: "[T] cure sought may be worse than the disease." Id. at 566 (Rutledge, J., concurring). This disapproval of "judicious tinkering" with district lines has by no means disappeared from the federal bench. See Judge Gee's concurrence in Kirksey v. Board of Supervisors, 554 F.2d 139, 156 (5th Cir.), cert. denied, 434 U.S. 968 (1977) (Gee, J., specially concurring).

is 369 U.S. 186 (1962).

" See, e.g., Cousins v. City Council, 466 F.2d 830, 844-45 (7th Cir.), cert. denied, 409 U.S. 893 (1972); Wells v. Rockefeller, 311 F. Supp. 48, 54 (S.D.N.Y.) (Cannella, J., concur- 
been adjudicated by the courts over the last twenty years have been based on two distinct and not entirely compatible theories. In some cases, courts have heard claims asserting that gerrymanders directed against racial groups constitute a type of racial discrimination or segregation..$^{15}$ In others, plaintiffs have argued that state districting schemes that diminish the power of identifiable political groups fall within the prohibition of unequal individual voting power articulated in Baker and Reynolds. ${ }^{18}$ The two approaches have not always been distinguished, largely because most gerrymander challenges have been brought by racial groups. ${ }^{17}$

This comment will argue that successful challenges to various sorts of districting plans may be founded upon a unified concept: dilution of voting power. ${ }^{18}$ The theory of voting dilution relies on a constitutional right of equality of voting power and presupposes that the importance of the individual vote lies in the ability of identifiable political groups to exercise political power. The characterization of the voting dilution cause of action as a voting rights claim-and not a claim of racial discrimination-has two important implications. First, the cause of action should be available to both racial and nonracial, politically cohesive groups. Second, the rationale underlying the voting dilution cause of action militates against a strict requirement of showing discriminatory intent in the drawing of the challenged districting plan. Although the failure of the courts to view districting challenges as voting power cases has generated contrary holdings and dicta, both propositions are consistent with a coherent view of the cause of action.

ring), aff'd, 398 U.S. 901 (1970); Sincock v. Gately, 262 F. Supp 739, 833 (D. Del. 1967); WMCA, Inc. v. Lomenzo, 238 F. Supp. 916 (S.D.N.Y.), aff'd, 382 U.S. 4 (1965).

${ }^{15}$ E.g., Wright v. Rockefeller, 376 U.S. 52, 54 (1964); Gomillion v. Lightfoot, 364 U.S. 339 (1960).

16 E.g., White v. Regester, 412 U.S. 755 (1973); Whitcomb v. Chavis, 403 U.S. 124 (1971); Fortson v. Dorsey, 379 U.S. 433 (1965). These challenges, generally called voting dilution claims, have most frequently been attacks on the peculiar problems of multimember districts.

17 See, e.g., Blacks United for Lasting Leadership, Inc. v. City of Shreveport, 571 F.2d 248 (5th Cir. 1978); Nevett v. Sides, 571 F.2d 209 (5th Cir. 1978); Lipscomb v. Wise, 551 F.2d 1043 (5th Cir. 1977), rev'd, 98 S. Ct. 2493 (1978); Dove v. Moore, 539 F.2d 1152 (8th Cir. 1976); Cousins v. City Council, 466 F.2d 830 (7th Cir.), cert. denied, 409 U.S. 893 (1972).

"s Most courts have applied the term "voting dilution" to describe only multimember districting cases. Judge Tjoflat's opinion in Nevett v. Sides, 571 F.2d 209 (5th Cir. 1978), for example, distinguished within the broad class of "qualitative" reapportionment cases those alleging gerrymander (fencing out or slicing up an interest group) from those attacking multimember or at-large districting plans, identifying only the latter as resting on a "dilution" theory. Id. at 216 . This comment treats voting dilution claims as coterminous with "qualitative" districting challenges. Voting dilution is the theory upon which some, but not all, gerrymanders may be found unconstitutional. 


\section{Districting Plans Subject to Voting Dilution Clatms}

Current judicial analysis of voting dilution claims is a response to the particular problem of multimember districting. Where there are cohesive majority and minority factions, if cumulative voting is not permitted, multimember districting can minimize the electoral power of a political minority by facilitating the election of an entire slate of candidates representing the majority. ${ }^{19}$ In the wake of the Reynolds requirement that election districts be of equal population, ${ }^{20}$ groups of voters attacked multimember districts as creating discriminatory disparities between majority and minority representation. $^{21}$ The Supreme Court, however, notwithstanding the effects of multimember districting plans, has not considered the consequences of such districting-without more-to be sufficient to invalidate all multimember schemes. ${ }^{22}$

In Fortson v. Dorsey, ${ }^{23}$ the first multimember districting case to reach the Supreme Court, plaintiffs alleged that populous districts with more than one representative denied the residents of those districts "a vote 'approximately equal in weight to that of' voters resident in single-member constituencies." ${ }_{24}$ The Court rejected the contention that plaintiffs were victims of discrimination, finding that legislators elected at-large from multimember districts adequately represented all the citizens of their districts. Although the Court declined to find multimember districts unconstitutional per $s e,^{25}$ it recognized that there might be constitutional impedi-

1. Allen v. State Bd. of Elections, 393 U.S. 544, 569 (1969); Kilgarlin v. Martin, 386 U.S. 120, 126 (1967) (Douglas, J., concurring); Chapman v. Meier, 372 F. Supp. 371, 391 (D.N.D. 1974) (Bright, J., dissenting), rev'd, 420 U.S. 1 (1975); Washington, Does the Constitution Guarantee Fair and Effective Representation to All Interest Groups Making Up the Electorate?, 17 How. L.J. 91 (1971); Note, Ghetto Voting and At-Large Elections: A Subtle Infringement Upon Minority Rights, 58 GEo. L.J. 989 (1970); Note, Multi-Member Legislative Districts: Requiem for a Constitutional Burial, 29 U. FrA. L. REv. 703 (1977).

24377 U.S. at 577.

21 Equal population is required to ensure "substantially equal . . . representation for all citizens." Id. at 568.

2 Whitcomb v. Chavis, 403 U.S. 124, 149, 156 (1971). But cf. Connor v. Finch, 431 U.S. 407, 415 (1977) (single-member districts preferred because "multimember districting . . . tend[s] to submerge electoral minorities and over-represent electoral majorities"). The Court has found the effect of multimember districting serious enough to require prior approval of such plans by the Attorney General under the Voting Rights Act. See Allen v. State Bd. of Elections, 393 U.S. 554 (1969) (construing 42 U.S.C. $\$ \$ 1971-1973 b b-4$ (1970)); cf. Beer v. United States, 425 U.S. 130 (1975) (prior approval required under 42 U.S.C. \& 1973c (1970)). In reaching this conclusion, the Court recognized that the adoption of a multimember plan may nullify voters' ability to elect candidates of their choice in much the same way as their outright disenfranchisement. Allen v. State Bd. of Elections, 393 U.S. at 569.

23 379 U.S. 433 (1965).

2 Id. at 437 .

${ }_{25}$ Whitcomb v. Chavis, 403 U.S. 124 (1971); Burns v. Richardson, 384 U.S. 73 (1966); 
ments to multimember schemes that "minimize or cancel out"2t the voting strength of a cohesive group. The Court, in Whitcomb $v$. Chavis, ${ }^{27}$ again upheld a plan that used multimember districts, but for the first time suggested the contours of a constitutional attack on such plans. It was not enough, said the Court, for the group to claim voting dilution because of suffering "the disaster of losing too many elections;",28 plaintiffs ${ }^{20}$ had not shown that multimember districts were "conceived or operated as purposeful devices to further racial or economic discrimination." ${ }^{30}$ Nor had plaintiffs shown that they were denied the opportunity to register to vote, to participate in slate-making, or to run for office on a major party ticket. ${ }^{31}$ The Court concluded that a plan would be struck down only if members of a minority were denied the opportunity "to participate in the political processes and to elect legislators of their choice." ${ }^{32}$

In White $v$. Regester, ${ }^{33}$ a plan similar to the one upheld in Chavis was overturned. Although the Court analyzed the two cases under a single equal protection theory, ${ }^{34}$ it held in Regester that the multimember districts used in Dallas and Bexar Counties violated the equal protection guarantee ${ }^{35}$ by discriminating against racial minorities in those counties. The Court accepted the plaintiffs' claims that their voting rights had been diluted because: there was a history of underrepresentation of black and Mexican-American interests; ${ }^{38}$ these minorities continued to suffer the effects of past

Fortson v. Dorsey, 379 U.S. 433 (1965).

${ }^{24}$ Burns v. Richardson, 384 U.S. 73, 88 (1966) (dictum); Fortson v. Dorsey, 379 U.S. 433, 439 (1965) (dictum).

2703 U.S. 124 (1971).

23 Id. at 153.

2 The plaintiffs were blacks and poor persons living in inner city Indianapolis, who were alleged to have "particular demographic characteristics rendering them cognizable as a minority interest group with distinctive interests in specific areas of the substantive law." Id. at 129.

s. Id. at 149.

st Id. at 149-53.

12 Id. at 149. Multimember districts have also been observed to be discriminatory against minorities because they force candidates to conduct a wider and more expensive campaign. Graves v. Barnes, 343 F. Supp. 704, 720-21 (W.D. Tex. 1972), aff'd in part sub nom. White v. Regester, 412 U.S. 755 (1973).

s 412 U.S. 755 (1973).

it See id. at 765-66.

ss The claim in one district was brought by Mexican-Americans, "an identifiable class for Fourteenth Amendment purposes," 412 U.S. at 767. This claim could not have been brought under the fifteenth amendment, which is only addressed to racial discrimination.

${ }^{3}$ Id. at 766. See Comment, Reapportionment and Minority Politics, 6 Colum. Humas Rugris L. REv. 107, 123-24 (1974) (suggesting that this difference between Regester and Chavis is a crucial one). See also Bonapfel, Minority Challenges to At-Large Elections: The Dilution Problem, 10 GA. L. Rev. 353, 369-71 (1976). 
discrimination; and there was a demonstrated insensitivity to the needs of minority citizens. Lower courts have subsequently relied on the criteria set forth in Regester to oyerturn discriminatory multimember districting plans. ${ }^{37}$

The Supreme Court has not squarely held that single-member districting plans are subject to the same constitutional challenge as plans unfairly drawing multimember district boundaries. Two recent opinions suggest, however, that the constitutional theory underlying Regester extends to discriminatory single-member districting. In Connor $v$. Finch, ${ }^{38}$ although the Court struck down a courtordered single-member districting scheme on malapportionment grounds, it went out of its way to address a voting dilution challenge. ${ }^{39}$ There would be little reason for the Court to discuss the "scattering" of minority voting concentrations ${ }^{40}$ and the minimization of minority voting strength ${ }^{41}$ unless these could form the basis for a judicially cognizable claim. In United Jewish Organizations $v$. Carey, ${ }^{42}$ the Court addressed the merits of a claim of a group of Hasidic Jewish voters that single-member district lines in New York City had been unconstitutionally drawn to create "safe" black districts, thus dividing the Hasidic community and splitting its vote. ${ }^{43}$ The Court concluded that the case was not one of "racial or political groups hav[ing] been fenced out of the political process and their voting strength invidiously minimized."44 Significantly, however, the Court did not say that such a claim would be inappropriate in this context.

Lower courts have consistently recognized that the voting dilution principle developed by the Court in the multimember district cases is equally applicable to challenges to all forms of gerrymanders. ${ }^{45}$ Indeed, it is difficult to see how this conclusion could be

" See, e.g., Bolden v. City of Mobile, 571 F. 2d 238 (5th Cir.), prob. juris. noted, 47 U.S.L.W. 3221, (U.S. Oct. 2, 1978) (No. 77-1844); Zimmer v. McKeithen, 485 F.2d 1297 (5th Cir. 1973) (en banc), aff'd sub nom. East Carroll Parish School Bd. v. Marshall, 424 U.S. 636 (1976).

331 U.S. 407,415 (1977).

3v Id. at 421-26 (dictum). The Court noted that while it need not reach the issue, it would give guidance to the district court in order to avoid further challenges to Mississippi's legislative apportionment before the 1979 elections. Id. at 421-22.

- Id. at 422 .

"Id. at 425 .

12430 U.S. 144 (1977).

is Id. at 162-68.

" Id. at 167 (quoting Gaffney v. Cummings, 412 U.S. 735, 754 (1973)). Before the Court, petitioners alleged diminution of their power as white voters, 430 U.S. at 154, not as Hasidic Jewish voters. The Court found white voters, as a group, to be fairly represented under the existing districting scheme.

13 Nevett v. Sides, 571 F.2d 209 (5th Cir. 1978); Robinson v. Commissioners Court, 505 F.2d 674, 678 (5th Cir. 1974); Moore v. Leflore County Bd. of Educ., 502 F.2d 621 (5th Cir. 1974). 
controverted. ${ }^{46}$ The opportunity "to participate in the political processes and elect legislators of [one's] choice" 47 may be destroyed as effectively by an artful crafting of district boundaries as by a multimember plan. The Fifth Circuit, in particular, has noted the broad applicability of the voting dilution rationale, stating most recently in Nevett $v$. Sides ${ }^{48}$ that the "constitutional requisites" for the multimember district claim should be no different from those for gerrymanders of single member districts that concentrate, fence out, or slice up a compact minority group. "In each instance, we are required to determine the same question, whether or not there has been an unconstitutional manipulation of electoral district boundaries so as to minimize or dilute the voting strength of a minority class or interest." 49

\section{Group Voting Power and the Individual's Right to Participate}

Chavis and Regester, taken together, provide at best a rough working test for identifying those cases in which a group's diminished political influence rises to the level of a constitutional deprivation of its members' right to vote. Although lower courts continue to apply this test to multimember districting and have extended it to all forms of gerrymanders, the precise requirements of the cause of action remain unclear. The first step in defining the current limits of the voting dilution cause of action is to examine in more detail the basis for the Court's decision in Regester.

\section{A. The Rationale of the Voting Dilution Cause of Action}

Most voting dilution cases have involved racial or ethnic groups allegedly excluded from the political process. The need to protect the individual's right to vote has as a result become blurred with the constitutionally distinct doctrine of the need to protect racial minorities from discrimination. Justice White's statement of the

"Manipulation of single member district boundaries embraces the same concerns unless it is thought that inquiry into the gerrymandering of single-member, but not multimember, district boundaries is precluded by the political question doctrine. See text and notes at notes 86-87 infra. One commentator has called a distinction between inquiry into multimember and single-member districting "intellectually unappealing." R. Drxon, supra note 6, at 484 .

17 White v. Regester, 412 U.S. 755, 766 (1973).

48 571 F.2d 209, 218-19 (5th Cir. 1978); accord, Cousins v. City Council, 466 F.2d 830, 849 n.12 (7th Cir.), cert. denied, 409 U.S. 893 (1972) (Stevens, Cir. J., dissenting).

1 571 F.2d at 219 (quoting Robinson v. Commissioners Court, 505 F.2d 674, 678 (5th Cir. 1974) (quoting Howard v. Adams County Bd. of Supervisors, 453 F.2d 455, 458 (5th Cir.), cert. denied, 407 U.S. 925 (1972))). 
voting dilution case in Regester did not make explicit whether the basis of the claim was racial discrimination, infringement of voting rights, or both.$^{50}$ In light of the precursors of Regester, ${ }^{51}$ however, it seems more sensible to consider the voting rights strand of the Court's reasoning to be fundamental.

1. Reynolds and Group Voting Rights. In Reynolds, which held malapportioned districts unconstitutional, the fourteenth amendment voting right was conceived as "individual and personal in nature." 52 The effect of districting schemes that give the same number of representatives to unequal numbers of voters was described as "identical" in effect to granting some voters more ballots than others..$^{53}$ But Reynolds can be read as providing the basis for a broader doctrine.

[E]very citizen has an inalienable right to full and effective participation in the political processes of his State's legislative bodies. Most citizens can achieve this participation only as qualified voters through the election of legislators to represent them. Full and effective participation by all citizens in state government requires, therefore, that each citizen have an equally effective voice in the election of members of his state legislature..$^{54}$

The Court's opinion suggests that the individual right to vote means more than the right to cast a ballot of numerically equal weight: the language of the opinion implies a requirement that all voters have an equal opportunity to affect election outcomes.

The "equally effective voice" mandated by Reynolds, if understood to mean a right to cast an equally significant vote in an election, can never be fully guaranteed. The voter in a swing district is far more likely to affect the results than a voter in a safe district. ${ }^{35}$ Similarly more potent is a vote in a district with low voter turnout.

so On the one hand, the Court cited Burns v. Richardson, 384 U.S. 73 (1966), and Fortson v. Dorsey, 379 U.S. 433 (1965), cases which are clearly based on nonracial conceptions of equality of voting power. On the other hand, the Court repeatedly referred to the "racial group" and to official racial discrimination. 412 U.S. at 765-70.

st E.g., Whitcomb v. Chavis, 403 U.S. 124 (1971); Fortson v. Dorsey, 379 U.S. 433 (1965).

32377 U.S. at 561. See the discussion of standing to sue in Baker v. Carr, 369 U.S. 186, 204-08 (1962). See generally Karst, The Supreme Court, 1966 Term-Forward: Equal Citizenship Under the Fourteenth Amendment, 91 Harv. L. REv. 1, 27-29 (1977).

ss 377 U.S. at 562-63.

st Id. at 565 .

ss 403 U.S. at 169. For example, a voter in a district that is 50 percent Democratic and 50 percent Republican wields a great deal more power than a voter in a district that is 80 percent Democratic and 20 percent Republican. 
In multimember districting challenges, ${ }^{56}$ the courts have rejected the argument that because an individual in a multimember district has a greater possibility of breaking tie elections than a voter in a single-member district, ${ }^{57}$ such schemes are unconstitutional. If read more broadly to include effective participation at some level of the electoral process-whether that be the slating of candidates, formulation of party policy, or influence in primary elections-this equal opportunity is still an unreachable ideal. The individual voter's actual political power will again necessarily vary with the demographically and politically diverse contexts of the electoral process.

It can be argued that although one person, one vote attempts to protect the individual's right to vote, implementation of the policy underlying the doctrine depends upon the equalization of voting power among groups of voters. ${ }^{58}$ Reynolds protected the individual vote by guaranteeing equal representation to geographical groups, ${ }^{59}$ on the underlying assumption that legislators "represent" equally well all the voters in their districts. In reality, however, decisive voting cleavages more often run along economic, ideological, or racial lines that do not correspond to the shape of election districts. Some voters feel better "represented" by a legislator in another district than by one elected by their own. The Supreme Court recently acknowledged this political reality in United Jewish Organizations $v$. Carey. ${ }^{80}$ According to the Court, the member of a political minority in one district is not denied his share of voting influence if his group controls a fair share of other districts. ${ }^{81}$ The Court thus divorced individual voting rights from the individual's effect on elections, making it possible to draw from Reynolds the further inference that the rule of one person, one vote protects groups of

st E.g., Whitcomb v. Chavis, 403 U.S. 124, 144-47 (1971) (majority opinion); id. at 168-69 (Harlan, J., dissenting on other grounds); Burns v. Richardson, 384 U.S. 73 (1966); Fortson v. Dorsey, 379 U.S. 433 (1965).

${ }^{37}$ See Banzhaf, One Man, ? Votes: Mathematical Analysis of Voting Power and Effective Representation, 36 Geo. WASH. L. REv. 808 (1968); Banzhaf, Multi-Member Electoral Districts: Do They Violate the "One Man, One Vote" Principle?, 75 Yale L.J. 1309 (1966).

${ }^{58}$ See Fortson v. Morris, 385 U.S. 231, 250 (1966) ("In simple terms, the vote is meaningless . . . unless it, taken in the aggregate with the votes of other citizens, results in effectuating the will of those citizens . . . .") (Fortas, J., dissenting); Casper, supra note 5 at 105.

53 377 U.S. at 565. Justice Frankfurter correctly perceived that the basis of plaintiffs' complaint in Baker v. Carr, 369 U.S. 186 (1962), was simply that their representatives were not sufficiently numerous or powerful, 369 U.S. at 300 (Frankfurter, J., dissenting), not that plaintiffs were denied the right to vote in the sense of casting their individual ballots. See Irwin, Representation and Election: The Reapportionment Cases in Retrospect, $67 \mathrm{MicH}$. L. REv. 729, 747-53 (1969).

c 430 U.S. 144 (1977).

"Id. at 166 n.24. But see id at $171 \mathrm{n} .1$ (Brennan, J., concurring). 
voters from having their political power unfairly diminished. ${ }^{82}$

The decisions of the Supreme Court subsequent to Reynolds have further developed this view of the congruence of the individual right to vote and group political power. In Fortson $v$. Dorsey, ${ }^{63} \mathrm{de}-$ cided the term after Reynolds, and again in Chavis, the Court suggested that the equal protection clause might protect "racial or political elements of the voting population" from having their voting strength minimized or cancelled out. ${ }^{65}$ In Regester, plaintiffs' voting dilution claim was upheld in terms leaving little doubt that a group right, rather than the individual's right to cast a ballot, was at stake: each of the elements of a successful voting dilution claim involved evidence of the group's lack of impact at the polls. ${ }^{86}$

2. Voting Dilution and Racial Discrimination. There was no suggestion in either Fortson or Chavis that the voting dilution cause of action was based upon a racial discrimination theory. Similarly, the voting dilution claim upheld in Regester, which was grounded in the non-racial line of precedent beginning with the holding of justiciability in Baker, is fully supportable as the vindication of a right to political participation by groups with identifiable cohesive political interests.

Unfortunately for the sake of doctrinal clarity, Regester did not rely unambiguously on nonracial grounds. The claim, brought by blacks and Mexican-Americans, ${ }^{67}$ was also supported on the theory that the multimember districting plan "enhanced the opportunity for racial discrimination." 68 There are two versions of the racial discrimination theory of Regester: first, that discrimination existed in the community and in the provision of social services to the minority groups; second, that the discrimination lay in the district-

2 Extending Reynolds to protect a minority group's voting rights does not imply, however, that such groups have a right to a proportionate number of seats in the legislature. See Kirksey v. Board of Supervisors, 554 F.2d 139, 142-43 (5th Cir.) (en banc), cert. denied, 434 U.S. 968 (1977); see note 110 infra. See also L. TRIBE, supra note 6, at $\S 13-9$ n.11. What is required is that, circumstances permitting, each political bloc have a proportional share of influence on the selection of candidates and on the actions of candidates once elected. These are the components of "political power" as that term is used in this comment.

379 U.S. 433 (1965).

-4 403 U.S. at 143 (1971).

os See also 379 U.S. at 439.

“ Kirksey v. Board of Supervisors, 554 F.2d 139, 143 n.10 (5th Cir.) (en banc), cert. denied, 434 U.S. 968 (1977) ("[T] he [Regester] factors themselves are more relevant to whether a group has access to the political decision-making process rather than to whether a particular individual is free to vote.").

${ }^{67}$ The district court dismissed the dilution claim of Republican plaintiffs. Graves v. Barnes, 343 Supp. 704, 734-35 (W.D. Tex. 1972), aff'd in part sub nom. White v. Regester, 412 U.S. 755 (1973).

412 U.S. at 766. 
ing plan itself, but was directed against black voters as blacks, not as members of a political faction.

The first version surfaced in the Court's discussion of the "cultural and economic realities of the Mexican-American community." 69 Single-member districts "were thought required to remedy" the legacy of invidious discrimination against this group of voters. ${ }^{70}$ Persuasive as these cultural and economic realities may be as a policy reason for special vigilance over the rights of oppressed ethnic minorities, it is difficult to see why the right to equality of treatment in these various areas, already independently protected in large measure by the fourteenth amendment and by statute, ${ }^{71}$ could give rise to a right to vote greater than that of other citizens.

The more appealing version of the racial ground for the Regester decision is the second: the gerrymander may be a direct attempt to curtail the voting rights of the racial minority, regardless of the political views of individual voters, because of a desire to exclude the group. ${ }^{72}$ In Gomillion $v$. Lightfoot, ${ }^{73}$ the decision of Tuskegee, Alabama, to change the city boundaries in order to eliminate virtually all of the city's black residents was characterized as a form of racial segregation and was overturned as a disenfranchisement of blacks, violative of the fifteenth amendment. ${ }^{74}$ The plaintiffs in Wright $v$. Rockefeller ${ }^{75}$ employed a similar racial segregation theory to challenge the gerrymander of many New York blacks and Puerto Ricans into one congressional district. The claim was rejected because plaintiffs failed to prove that the districts were carved along

"Id. at 768-69.

70 Id. at 769; cf. Katzenbach v. Morgan, 384 U.S. 641, 653 (1966) (extension of the right to vote to Spanish speaking voters justified in part to combat discrimination in the provision of social services).

${ }^{71}$ In some circumstances discrimination in the provision of social services can be attacked and remedied directly. See Hawkins v. Town of Shaw, 437 F.2d 1286, rehearing denied, 461 F.2d 1171 (5th Cir. 1971). Discrimination in employment, housing, and education can also be attacked through the equal protection clause or under various statutes. E.g., 42 U.S.C. $\S \S 1981$, 1982, or 2000 e (1974).

Discrimination by a political party in the selection of its members may, however, be immune from direct attack. Ordering a party to admit more members of a minority group could be held to interfere with party members' freedom of association. Cf. Brown v. O'Brien, 469 F.2d 563, 570-72, (D.C. Cir.), vacated, 409 U.S. 816 (1972) (Democratic Party has the right to determine the qualifications of its convention delegates).

${ }^{72}$ Cf. Whitcomb v. Chávis, 403 U.S. 124, 150-53 (1971) (black voters harmed, if at all, as Democrats rather than as blacks).

73364 U.S. 339 (1960).

"Id. at 346. The case could also have been decided under the fourteenth amendment, see id. at 349 (Whittaker, J. concurring), and has been cited as if it were. Whitcomb v. Chavis, 403 U.S. at 149. See Clinton, supra note 11, at 6-10; R. Drxon, supra note 6, at 117. Compare Gomillion with City of Richmond v. United States, 422 U.S. 358 (1975).

73376 U.S. 52 (1964). 
racial lines ${ }^{76}$ or that the plaintiff groups were disadvantaged by the scheme. ${ }^{77}$

The Gomillion approach is vulnerable to the criticism that gerrymandering injures the minority group only in its capacity as a political faction. If members of the minority voted no differently from the population as a whole, the gerrymander would have no effect, either on the composition of the elected officiary or on the political power of the minority. It is the political, not the racial, character of the group that is significant. Since the right to political participation can be derived from the voting rights theory of Baker and Reynolds, the additional racial ground for the voting dilution claim is superfluous.

\section{B. Voting Dilution Claims of Nonracial Groups}

If the right of all citizens to an equally effective voice in the political process is understood as necessarily involving the protection of voting groups, the voting dilution cause of action derived from this right should be available to nonracial as well as racial groups of voters. Neither the Supreme Court nor any other federal court, however, has overturned a districting plan challenged entirely on a nonracial basis. On the contrary, in 1965, the Supreme Court affirmed, per curiam, an appellate court judgment holding partisan gerrymanders nonjusticiable. ${ }^{78}$ This position has generally been adopted by the lower courts. ${ }^{79}$

Four arguments might be made for limiting gerrymander challenges to racial or ethnic groups. First, it must be acknowledged that the fourteenth, as well as the fifteenth, amendment was specifically designed for the protection of the civil rights of the racial minority ${ }^{80}$ The courts have thus applied the amendment far more exactingly

${ }^{76}$ Id. at 56.

"Id. at 58. The case was complicated by the intervention of a group of blacks, including Congressman Adam Clayton Powell, who supported the gerrymander as a means of ensuring black representation. $R$. Dixon, supra note 6 , at 465 .

${ }_{77}$ WMCA, Inc. v. Lomenzo, 382 U.S. 4 (1965) (per curiam). Mr. Justice Harlan, concurring, emphasized the Court's agreement that partisan gerrymanders are beyond judicial review. Id. at 6.

7 Cousins v. City Council, 466 F.2d 830, 844-45 (7th Cir.), cert. denied, 409 U.S. 893 (1972); Wells v. Rockefeller, 311 F. Supp. 48, 52 (S.D.N.Y.), aff'd mem., 398 U.S. 901 (1970) (Cannella, J., concurring); Sincock v. Gately, 262 F. Supp. 739, 833 (D. Del. 1967); Kilgarlin v. Martin, 252 F. Supp. 404, 432-33 (S.D. Tex. 1966), rev'd on other grounds sub nom. Kilgarlin v. Hill, 386 U.S. 120 (1967); Bush v. Martin, 251 F. Supp. 484, 510, 513 (S.D. Tex. 1966); Meeks v. Avery, 251 F. Supp. 245, 250 (D. Kan. 1966); Sims v. Baggett, 247 F. Supp. 96, 104 (N.D. Ala. 1965).

kn Whitcomb v. Chavis, 403 U.S. 124, 149 (1971); The Slaughter-House Cases, 83 U.S. (16 Wall.) 36 (1873). 
where the rights of blacks and other ethnic minorities are involved;81 the rights of other groups might not merit such vigilance. This view was sometimes espoused by Justice Douglas, who argued in his Chavis dissent that the racial gerrymander is governed by a separate constitutional standard..$^{82}$ Second, the long unchallenged history of the political gerrymander might be regarded as supporting the view that the practice is not constitutionally prohibited..$^{83}$ In one decision striking down a racial gerrymander, the Court was careful to distinguish the case before it from the "familiar abuses of gerrymandering." 84 Third, the difficulty involved in identifying political and other interest groups makes the nonracial, nongeographic case far less susceptible to judicial decision than cases such as Reynolds or Regester. The unstable and ill-defined nature of nonracial groups makes the courts' line-drawing task less manageable. ${ }^{85}$ The fourth argument, which builds on the first three, is that nonracial gerrymandering is a nonjusticiable political question. It is argued that a textually demonstrable commitment to a "coordinate" political branch may be found in Article I, section $4^{86}$ and that there is a lack of judicially manageable standards for enforcement of the group voting right. ${ }^{87}$

Two of the above arguments can be answered with little difficulty. The assertion that the political gerrymander occupies a

" See, for example, Klahr v. Williams, 339 F. Supp. 922 (D. Ariz. 1972), in which the state districting plan was upheld in part despite its partisan purpose, id. at 926 , but partly overturned because of its effect on Navajo voters, id. at 927.

3 It is said that if we prevent racial gerrymandering today, we must prevent gerrymandering of any special interest group tomorrow, whether it be social, economic, or ideological. I do not agree. Our Constitution has a special thrust when it comes to voting; the Fifteenth Amendment says the right of citizens to vote shall not be "abridged" on account of "race, color, or previous condition of servitude."

Whitcomb v. Chavis, 403 U.S. at 180 (Douglas, J., dissenting). But see Cousins v. City Council, 466 F.2d 830, 851 n.18 n.18 (7th Cir.), cert. denied, 409 U.S. 893 (1972) (Stevens, Cir. J., dissenting). Justice Douglas was not entirely consistent. Compare Whitcomb (Douglas, J., dissenting) with Williams v. Rhodes, 393 U.S. 23, 39 (1968) (Douglas, J., concurring).

s See Gaffney v. Cummings, 412 U.S. 735, 753 (1973). The Court seemed to assume that partisan political considerations must always be a part of the districting process.

* Gomillion v. Lightfoot, 364 U.S. 339, 341 (1960).

zs To some extent, these difficulties are present in the racial cases as well, since community voting patterns must be determined in order to establish the discriminatory effect of the challenged plan and suggested remedies. Allegations of racially polarized voting are a common feature in the plaintiff's case. See, e.g., Nevett v. Sides, 571 F.2d 209, 223 n.16 (5th Cir. 1978); Bolden v. City of Mobile, 571 F.2d 238, 243 (5th Cir. 1978), prob. juris. noted, 47 U.S.L.W. 3221 (U.S. Oct. 2, 1978) (No. 77-1844); Wallace v. House, 515 F.2d 619, 622 (5th Cir. 1975). Moreover, in many cases, examination of past election returns may be a reliable means of determining the political impact of a given plan. See Gaffney v. Cummings, 412 U.S. 735, 738 (1973) (districting plan based on voting patterns in past three elections).

* U.S. Const. art I, $₹ 4$.

n7 See Baker v. Carr, 369 U.S. 186, 217 (1962). 
stronger historical position and is therefore deserving of judicial deference is simply not convincing. Remnants of the racial discrimination that existed before the first gerrymanders have not been deemed entitled to special protection from judicial scrutiny ${ }^{88} \mathrm{Simi}$ larly, malapportioned districts in Tennessee had existed for 60 years before being held to pose a justiciable controversy in Baker v. Carr. ${ }^{89}$ The argument that political gerrymanders lie in an area committed to a coordinate branch of government is contrary to the language of Baker that "it is the relationship between the judiciary and the coordinate branches of the Federal Government, and not the federal judiciary's relationship to the States, which gives rise to the 'political question." "90 The second part of the political question objection is somewhat more troublesome. The criteria developed by the cases following Regester, ${ }^{91}$ however, would seem to provide manageable standards for claims of nonracial, as well as racial, groups.

Even though the nonjusticiability arguments, in the aggregate, have some force, the logic of the voting dilution cases impels the recognition of claims of nonracial groups. For example, in Chavis the Court acknowledged the difficulty of limiting the concept to its original racial context:

The District Court's holding, although on the facts of this case limited to guaranteeing one racial group representation, is not easily contained. It is expressive of the more general proposition that any group with distinctive interests must be represented in legislative halls if it is numerous enough to command at least one seat and represents a majority living in an area sufficiently compact to constitute a single-member district. ${ }^{92}$

The Court rejected the contention that there was a right to representation of all political groups, but seemed to assume that if such a right were recognized, it would extend to groups such as Democrats, Republicans, union workers, university communities, religious sects, or ethnic groups, if their interests were "distinctive." 93 The Court's reasoning implies that a right to participation, the right acknowledged by the Court in Regester, should extend to all such groups. Indeed, from the first recognition

** See Cousins v. City Council, 466 F.2d 830, 851 n.18 (7th Cir.), cert. denied, 409 U.S. 893 (1972) (Stevens, Cir. J., dissenting).

* 369 U.S. 186, 191-93, 237 (1962).

so Id. at 210.

"See, e.g., Zimmer v. McKeithen, 485 F.2d 1297 (5th Cir. 1973), aff'd per curiam on other grounds sub nom. East Carroll Parish School Bd. v. Marshall, 424 U.S. 636 (1976).

32403 U.S. at 156 (footnote omitted).

"Id. 
of the possibility of the voting dilution challenge by a nongeographical group in the Fortson dictum, ${ }^{94}$ the message has been repeated: a districting scheme that "would operate to minimize or cancel out the voting strength of racial or political elements of the voting population" might be vulnerable to constitutional attack. ${ }^{95}$

The Court's adjudication of the claim in Gaffney $v$. Cummings ${ }^{96}$ provides further support. Connecticut Democrats alleged that the challenged districting scheme contained "a built-in bias in favor of the Republican party." "If claims of partisan gerrymanders were nonjusticiable, or if there were no such cause of action on behalf of nonracial groups, then the Court should have ordered the cause of action dismissed. Instead, it heard the merits, ${ }^{98}$ noting that "[w]hat is done in so arranging for elections, or to achieve political ends or allocate political power, is not wholly exempt from judicial scrutiny under the Fourteenth Amendment." 99

The Fifth Circuit, in dictum, recently suggested the justiciability of voting dilution claims by all political groups, discussing discrimination against a racial group as a subclass of gerrymanders actionable on a voting dilution theory. ${ }^{100}$ Addressing the issue more directly, Judge, now Justice, Stevens, in his dissent in Cousins $v$.

" Fortson v. Dorsey, 379 U.S. 433, 439 (1965).

is Id. (emphasis added); accord, Whitcomb v. Chavis, 403 U.S. 124, 144 (1971); Burns v. Richardson, 384 U.S. 73, 88 (1966); cf. Cousins v. City Council, 466 F.2d 830, 844 (7th Cir.), cert. denied, 409 U.S. 893 (1972) (noting that the Fortson dictum no longer represents the prevailing view of the Court). This view appeared twenty years earlier in Justice Black's dissent in Colegrove v. Green, 328 U.S. 549, 566-74 (1946), when he wrote that "legislation which must inevitably bring about glaringly unequal representation in the Congress in favor of special classes and groups should be invalidated." Id. at 571. Justice Black interpreted article I of the Constitution to guarantee that "[a]ll groups, classes, and individuals shall to the extent that is practically feasible be given equal representation in the House of Representatives." Id. at 570-71.

* 412 U.S. 735 (1973).

17 Id. at 739.

"Similarly, in Graves v. Barnes, 343 F. Supp. 704 (W.D. Tex. 1972), aff'd in part sub nom. White v. Regester, 412 U.S. 755 (1973), the district court did not question the standing of a group of Republican voters to challenge the Texas Senate and House districting schemes. With respect to the Senate districts the court found no evidence of voting dilution; with respect to the House of Representatives, the court did not reach the issue since it found the relief requested by the Republicans "subsumed" in the relief granted to the black and Mexican-American voters. 343 F. Supp. at 734-35.

The Gaffney Court held for the defendants, saying that the "spirit of 'political fairness' underlying this plan is not only permissible, but a desirable consideration." 412 U.S. at 752. The plan had been crafted to produce a legislative reflection of the partisan division of the state.

"Id. at 754.

${ }_{100}$ Nevett v. Sides, 571 F.2d 209, 216 (5th Cir. 1978) ("The issue in dilution cases, therefore, is not whether a given group elects a minimum number of candidates, and the standards are not different when ... . the interest binding the group is one of race."). 
City Council, ${ }^{101}$ argued that, following the Baker $v$. Carr line of cases, the rationale of the voting dilution attack on gerrymandering applies with equal force to ethnic, political, or racial groups. ${ }^{102}$ At the heart of this position is the recognition that unfettered participation in the political processes is a protected right of all citizens. As Judge Stevens noted, gerrymandering is by its nature directed at groups behaving as political factions. "The mere fact that a number of citizens share a common ethnic, racial, or religious background does not create the need for protection against gerrymandering . . . . [T] he characteristic of the group which creates the need for protection is its political character."103 To grant blacks, as $a$ political group, more protection than others as political groups amounts to unfair treatment that could itself be characterized as "invidious". 104

This expansive view of the groups protected under the voting dilution theory does not mean that any group, no matter how small, ${ }^{105}$ or how thinly spread throughout the political jurisdiction, ${ }^{106}$ may state a cause of action for unconstitutional gerrymandering. Rather, it is limited to those groups that have enough members to control at least one district and are geographically situated to allow a practicable redrawing of district lines to increase their political power. ${ }^{107}$ These limitations, coupled with the stiff requirements of

in 466 F.2d 830 (7th Cir.), cert. denied, 409 U.S. 893 (1972) (Stevens, Cir. J., dissenting).

102466 F.2d at 851.

${ }^{103}$ Id. at 852. See City of Petersburg v. United States, 354 F. Supp. 1021, 1025 (D.D.C. 1972), aff'd mem. 410 U.S. 962 (1973); Note, United Jewish Organizations v. Carey and the Need to Recognize Aggregate Voting Rights, 87 YALE L.J. 571, 590 n.106 (1978).

To say that racial minorities must be distinct political factions is not necessarily to say that their views on most political issues must diverge from those of other voters. A racial minority alleging dilution may agree with other voters on most questions of public policy and disagree only on which candidates it favors, and may favor different candidates only because they are members of the same racial minority. In such a situation, the race of candidates is a political issue dividing voters into factions.

14 466 F.2d at 852 (Stevens, J., dissenting). But see Note, supra note 103, arguing that only groups cognizable under the fifteenth amendment should have a right to representation.

tos See Lipscomb v. Wise, 551 F.2d 1043, 1047-48 (5th Cir. 1977), rev'd on other grounds, 98 S. Ct. 2493 (1978); Cousins v. City Council, 503 F.2d 912, 921-22 (7th Cir. 1974), cert. denied, 420 U.S. 992 (1975).

100 In Cousins v. City Council, 503 F.2d 912 (7th Cir. 1974), cert. denied, 420 U.S. 992 (1975), the claim of Puerto Rican voters in Chicago that their voting stength had been diminished by means of unconstitutional gerrymandering was rejected because the members of the group were so scattered among three or four wards that it would be impossible to create a Puerto Rican majority ward. Id. at 921 .

${ }^{107}$ Cf. Whitcomb v. Chavis, 403 U.S. at 156 (denying a right to representation to such groups). In Vollin v. Kimbel, 519 F.2d 790 (4th Cir.), cert. denied, 423 U.S. 936 (1975), black voters, comprising six percent of the electorate, were held unable to state a voting dilution claim. 
the plaintiff's case, ${ }^{108}$ should prevent the undue proliferation of litigation.

\section{Elements of the Platntiff's Case}

The elements of the voting dilution case were described in Regester:

The plaintiff's burden is to produce evidence to support findings that the political processes leading to nomination and election were not equally open to participation by the group in question - that its members had less opportunity than did other residents in the district to participate in the political processes and to elect legislators of their choice. ${ }^{100}$

The Court demanded more than the mere showing that the group allegedly discriminated against had not had legislative seats in proportion to its size as a voting bloc, ${ }^{10}$ but failed to articulate the relevance of the additional requirements set forth. Application of this test suggested in Regester has often proceeded without a clear recognition of the ultimate issue in the case. The courts have not known whether to require the plaintiff to show a diminution of voting power, a pattern of racial discrimination, or both. This confusion has led to uncertainty about the types and weight of evidence relevant to the elements of the test.

A principled resolution of the voting dilution cases proceeds from a recognition that the ultimate issue is whether the political power possessed by a particular group is less than would be indicated by its numbers, and less than it would be with different district boundaries. Political power, as used here, is measured by influence on the nomination and election of candidates and the responsiveness of public officials to the interests and opinions of the

108 See pt. III infra.

in 412 U.S. 755, 765-66 (1973). In setting forth the standards that underlie these cases, the Supreme Court was cautious not to lay down a rigid formula for decision. Instead, the Court upheld the findings of the district court, "representing as they do a blend of history and an intensely local appraisal of the design and impact of the . . . multimember district in the light of past and present reality, political and otherwise." Id. at 769-70.

110 Id. at 765-66. But cf. Beer v. United States, 425 U.S. 130 (1976) (proportional representation as measure of equality of access under $\$ 5$ of the Voting Rights Act, 42 U.S.C. 8 $1973 \mathrm{c}$ (1974)). The lower courts have consistently recognized that "it is not enough to prove mere disparity between the number of minority residents and the number of minority representatives." Zimmer v. McKeithen, 485 F.2d 1297, 1305 (5th Cir. 1973), aff'd per curiam on other grounds sub. nom. East Carroll Parish School Bd. v. Marshall, 424 U.S. 636 (1976); accord, Kirksey v. Board of Supervisors, 554 F.2d 139, 143 (5th Cir.) (en banc), cert. denied, 434 U.S. 968 (1977); Bradas v. Rapides Parish Police Jury, 508 F.2d 1109, 1112 (5th Cir. 1975). 
group. ${ }^{111}$ This diminution of political power, however, must be something more than a demonstration that were district lines drawn differently, the political fortunes of the group would be improved. Rather, the group must show a "substantial" impairment of its political power; it must demonstrate "some fundamental unfairness in the electoral system."112

Understood in this way, there are two parts to the plaintiffs' required showing. First, plaintiffs must show that the challenged plan significantly diminishes their influence, as a group, on election results. Second, they must show that this diminution of political influence is not compensated for in other stages of the political process: for example, the nomination of candidates and the behavior of officials toward the groups after election. ${ }^{113}$

\section{A. The Group's Influence at the Polls}

In Regester, the Court found a diminution in electoral influence of blacks in Dallas from the facts that only two blacks, both whitesupported, had been elected to the Texas House of Representatives from Dallas since Reconstruction, and that a white-dominated organization that employed racial campaign tactics in white precincts so controlled Dallas elections that it did not need the support of the black community."14 The organization thus did not "exhibit good. faith concern for the political and other needs and aspirations of the Negro community."115 Especially where there are two hostile voting blocs in a community, the central issue will often be the inability of members or allies of one group to be elected. One court has noted that the allegation that no black has been elected to the city council because of the at-large system "may in itself indicate that minorities have been denied an equal influence in the political process."116 The election of isolated members of the minority need not, however, be decisive against the plaintiffs, ${ }^{117}$ nor does the lack of elected

III See generally Zimmer v. McKeithen, 485 F.2d 1297 (5th Cir. 1973), aff'd per curiam on other grounds sub nom. East Carroll Parish School Bd. v. Marshall, 424 U.S. 636 (1976).

112 Wallace v. House, 515 F.2d 619, 633 (5th Cir.), vacated on other grounds, 425 U.S. 947 (1976).

is As a practical matter, plaintiffs' right to relief will also depend on their ability to show that another plan can be designed that will provide them with a fair share of political power. See text and notes at notes $238-43$ infra.

i14 412 U.S. 755 (1973).

113 Id. at 767.

III Kendrick v. Walder, 527 F.2d 44, 48 (7th Cir. 1975).

117 Zimmer v. McKeithen, 485 F.2d 1297, 1307 (5th Cir. 1973), aff'd per curiam on other grounds sub nom. East Carroll Parish School Bd. v. Marshall, 424 U.S. 636 (1976) (without approving the constitutional holding of the appellate court). 
members of the minority - without more - establish the voting dilution claim. ${ }^{118}$

Where there are more than two identifiable political groups making up the electorate, a simple comparison of the population of the group with its numbers of elected officials is particularly inadequate to determine the group's influence at the polls. If a minority voting bloc is in a position to determine the outcome among candidates of other opposing factions, it may wield decisive political power. Those candidates will need to demonstrate attention to the minority's concerns in order to win its critical votes. ${ }^{119}$

To calculate a group's ability to affect election results, a court would have to count the number of "safe" districts controlled by the group and increase that figure by some fraction of the districts in which the group sometimes wins and those where the group is able to command the attention of other candidates. ${ }^{120}$ Any shortfall in voting influence must be proven attributable to the challenged plan. ${ }^{121}$

The Fifth and Seventh Circuits have noted several factors that will enhance a claim of voting dilution: districts that are especially large, ${ }^{122}$ or non-compact, ${ }^{123}$ majority vote requirements, ${ }^{124}$ antisingle-shot voting provisions, ${ }^{125}$ and the lack of provision for at-large

11s Whitcomb v. Chavis, 403 U.S. at 153.

11' See Greater Houston Civic Council v. Mann, 440 F. Supp. 696, 700 (S.D. Tex.) (1977) ("to disestablish the present order in favor of single district representation would necessarily strip the minorities of a goodly measure of their current city wide political potency").

120 See Cousins v. City Council, 503 F.2d 912 (7th Cir. 1974), cert. denied, 420 U.S. 992 (1975), where the court counted districts with large black minorities as representing black political strength. See also Panior v. Iberville Parish School Bd., 536 F.2d 101, 104 (5th Cir. 1976) (considering the impact on election outcomes of substantial black minorities in districts); Moore v. Leflore County Bd. of Election Comm'rs, 502 F.2d 621 (5th Cir. 1974) (invalidating a plan creating black majorities in all districts because the thinness of the majorities might perpetuate white control); Howard v. Adams County Bd. of Supervisors, 453 F.2d 455 (5th Cir.), cert. denied, 407 U.S. 925 (1972) (approving a plan where the 48 percent black minority controlled one safe seat out of five, constituted half of anothes district, and close to half of a third, even though plaintiffs' proposal would have created two safe black seats); Dove v. Moore, 539 F.2d 1152, 1155 n.4 (8th Cir. 1976) (blacks were found to wield political power by being a large minority in every official's constituency).

121 Kendrick v. Walder, 527 F.2d 44, 48 (7th Cir. 1975) (effect must be "as a result of the method of apportionment"); Wallace v. House, 515 F.2d 619, 633 (5th Cir. 1975), vacated on other grounds, 425 U.S. 947 (1976) (plan must be a "tool" of racial discrimination); Taylor v. McKeithen, 499 F.2d 893, 896 (5th Cir. 1974) (plaintiff must show a "nexus" between district lines and the denial of access to the political process).

122 Zimmer v. McKeithen, 485 F.2d at 1305. See also Whitcomb v. Chavis, 403 U.S. at 143.

${ }^{123}$ Cousins v. City Council, 503 F.2d 912, 922 (7th Cir. 1974), cert. denied, 420 U.S. 992 (1975).

12 Zimmer v. McKeithen, 485 F.2d at 1305 . See also White v. Regester, 412 U.S. at 766.

125 Wallace v. House, 515 F.2d 619, 624 (1975), vacated on other grounds, 425 U.S. 947 
candidates running from particular geographical subdistricts. ${ }^{126}$ These factors all suggest that the plan has the effect of depriving a minority of its opportunity to exert influence at the polls. Proof that the plan grants a group less influence at the polls than is warranted by its proportionate population share is not decisive, however. The fourteenth amendment does not protect groups from losing elections, where their rights to meaningful participation in other facets of the political processes are unimpaired. ${ }^{127}$

\section{B. Participation in the Political Processes}

The test for voting dilution developed by the lower courts, particularly the Fifth Circuit, goes beyond a surface comparison of size of population to number of representatives, and beyond other overt manifestations of electoral power, to evaluate whether a group exerts political power at earlier and later stages of the political process. ${ }^{128}$ The most often cited explication of the requirements of Regester is the Fifth Circuit's opinion in Zimmer v. McKeithen, ${ }^{129}$ which sets forth the criteria for establishing voting dilution.

The Fifth Circuit test consists of four principal factors, the aggregate of which will establish the claim. ${ }^{130}$ First, the plaintiffs ${ }^{131}$ may prove an exclusion from the process of slating candidates. The evidence may be particularly important where one political party is. dominant and the primary is effectively the election. ${ }^{132}$ Where there is an open primary system without party endorsement, there is no exclusion from the slating process. ${ }^{133}$ If the minority group participates fully and effectively in the candidate selection of a major party, it may be inferred that its underrepresentation is a result of

(1976); Zimmer v. McKeithen, 485 F.2d at 1305.

tzo Zimmer v. McKeithen, 485 F.2d at 1305. See also Whitcomb v. Chavis, 403 U.S. at 144-45.

127 Whitcomb v. Chavis, 403 U.S. at 153.

123 Zimmer v. McKeithen, 485 F.2d at 1305; Hendrix v. Joseph, 559 F.2d 1265, 1271 (5th Cir. 1977). See 87 Harv. L. Rev. 1851 (1974). See also Kirksey v. Board of Supervisors, 554 F.2d 139, 143 (5th Cir.) (en banc), cert. denied, 434 U.S. 968 (1977) (demonstrating that not all four factors listed in text infra need be proven).

18 485 F.2d 1297 (5th Cir. 1973), aff'd per curiam on other grounds sub nom. East Carroll Parish School Bd. v. Marshall, 424 U.S. 636 (1976).

130485 F.2d at 1305.

131 The plaintiffs need not be a minority in the strict sense, but merely a politically disadvantaged group. Id. at 1303-04.

132 Compare Whitcomb v. Chavis, 403 U.S. at 150-51 with White v. Regester, 412 U.S. at 766-67. See also Wallace v. House, 515 F.2d 619, 624 (5th Cir. 1975), vacated, 425 U.S. 947 (1976).

${ }^{133}$ McGill v. Gadsen County Comm'n, 535 F.2d 277, 280 (5th Cir. 1976). Evidence of this kind would be particularly important in establishing claims of nonracial groups. 
voter apathy or poor political organization, rather than of voting dilution.

Second, plaintiffs may show that the legislators elected are not responsive to the group's interests. Hostility of government officials toward the group, ${ }^{134}$ discriminatory provision of government services, ${ }^{135}$ or discrimination in government hiring are indicative of such unresponsiveness. ${ }^{136}$ Since public officials serve a variety of functions, it is important not to ignore the possibility that a representative whose voting record appears uncongenial to a group may be responsive in other ways. The responsiveness factor may be of small weight in hard cases, ${ }^{137}$ both because of difficulties of proof ${ }^{138}$ and because of the possible impropriety of judicial scrutiny of the performance of elected officials. ${ }^{139}$ Perhaps most important, because it is difficult to predict how responsive future officials will be, ${ }^{140}$ no districting plan making significant changes can be evaluated in terms of responsiveness.

Third, plaintiffs may establish that the policy underlying the districting scheme is "tenuous,"141 making plausible the inference that the scheme is merely a pretext for shutting the minority out from power. ${ }^{142}$ State policies in favor of multimember districts, ${ }^{143}$

12 Brown v. Moore, 428 F. Supp. 1123, 1129-31, 1140-41 (S.D. Ala. 1976) (officials uncooperative in implementing desegregation).

${ }_{135}$ Yelverton v. Driggers, 370 F. Supp. 612, 618 (M.D. Ala. 1974); cf. Dove v. Bumpers, 364 F. Supp. 407, 410-12 (E.D. Ark. 1973) (finding no discrimination in services), vacated, 497 F.2d 895 (8th Cir. 1974). See also Bonapfel, supra note 36 at 379-87 (1976).

${ }^{136}$ Hendrix v. Joseph, 559 F.2d 1265, 1269 (5th Cir. 1977); David v. Garrison, 653 F.2d 923, $929-30$ (5th Cir. 1977).

17 See Zimmer v. McKeithen, 485 F.2d at 1306. But see Nevett v. Sides, 571 F.2d 209, 223 n.19 (5th Cir. 1978).

${ }_{130}$ In some cases, especially involving racial minorities in the South, the proof is not difficult; the record is "clear and stark." See, e.g., Kirksey v. Board of Supervisors, 554 F.2d 139, 143-44 (5th Cir.) (en banc), cert. denied 434 U.S. 968 (1977); Reese v. Dallas County, 505 F.2d 879, 885-86 (5th Cir. 1974).

13 Referring to judicial investigation into the performance of legislators, Justice Harlan remarked: "If there are less appropriate subjects for federal judicial inquiry, they do not come readily to mind." Whitcomb v. Chavis, 403 U.S. at 170 (Harlan, J., concurring).

iv See, e.g., Van Cleave v. Town of Gibsland, 380 F. Supp. 135, 138 (W.D. La. 1974).

III The "tenuousness" of the state policy may more properly be viewed as a response to the defendant's affirmative defense. See text and notes at notes 167-70 infra. The Fifth Circuit, however, seems not to distinguish the factor from other parts of plaintiff's case. See, e.g., Nevett v. Sides 571 F.2d 209 (5th Cir. 1978).

112 Robinson v. Commissioners Court, 505 F.2d 674, 679 (5th Cir. 1974) (finding that district lines were redrawn after the election of the first black precinct captain); $c f$. White $v$. Regester, 412 U.S. 755 (1973) (long-standing policy of multimember districts in two cities overturned); Wallace v. House, 515 F.2d 619, 633 (5th Cir. 1975), vacated, 425 U.S. 947 (1976) (long-standing state policy in favor of at-large elections supported retention of a swing seat elected at large).

${ }^{113}$ Dove v. Moore, 539 F.2d 1152, 1153 (8th Cir. 1976). 
preserving historical political boundaries, ${ }^{144}$ and preserving the districts of incumbents deserve judicial deference. ${ }^{145}$ Other policies, such as the equalization of road and bridge mileage, may carry little weight. ${ }^{146}$ Where the policies are of recent vintage, they are generally considered to be tenuous. ${ }^{147}$

Fourth, plaintiffs might prove the existence of past discrimination against the group, making it more likely that the plan operates to disadvantage them in the exercise of their vote. ${ }^{148}$ It is often difficult to decide how much weight to give to past, discontinued discriminatory policies. ${ }^{149}$ When these past policies retain present effect, however, such as a dearth of minority members registered to vote, ${ }^{150}$ they are still significant. Courts will often look to discrimination in the private sector, as well as by government, ${ }^{151}$ but the most important evidence is of discrimination which "touched the right of [the group] to register and vote and to participate in the democratic processes." 152 Yet, finding that past discrimination has caused a present diminution in voting power does not necessitate finding voting dilution. ${ }^{153}$ The Fifth Circuit has properly recognized that a shift in the burden of proof is appropriate where plaintiffs have established a history of past discrimination. Defendants should then bear the burden of proving that the incidents of past discrimination have been removed, at least where the discrimination is not remote in time. ${ }^{154}$ Otherwise, plaintiffs would have to prove not

I' See Whitcomb v. Chavis, 403 U.S. at 162 n.42; cf. Abate v. Mundt, 403 U.S. 182 (1971) (some mathematical inexactness acceptable in apportionment given such a policy, in absence of allegation of any bias for or against any group).

${ }^{145}$ White v. Weiser, 412 U.S. 783, 797 (1973); Cousins v. City Council, 503 F.2d 912, 917 \& n.11b (7th Cir. 1974), cert. denied, 420 U.S. 992 (1975).

1" Kirksey v. Board of Supervisors, 554 F.2d 139, 151 (5th Cir.) (en banc), cert. denied, 434 U.S. 968 (1977). But see Moore v. Leflore County Bd. of Comm'rs, 502 F.2d 621, 625 (5th Cir. 1974) (equalization of road mileage and land area called "extremely important here").

117 See cases cited in note 142 supra.

14 White v. Regester, 412 U.S. at 766-67. See also United Jewish Organizations v. Carey, 430 U.S. 144, 165 (1977) (approving a districting plan which represented "no racial slur or stigma" against the plaintiff group).

10 See, e.g., Bradas v. Rapides Parish Police Jury, 508 F.2d 1109, 1112-13 (5th Cir. 1975).

150 Hendrix v. Joseph, 559 F.2d 1265, 1270 (5th Cir. 1977); Zimmer v. McKeithen, 485 F.2d at 1305 .

151 E.g., Kendrick v. Walder, 527 F.2d 44, 49 (7th Cir. 1975) (all-white private schools and employment discrimination).

132 White v. Regester, 412 U.S. at 766.

1s McGill v. Gadsen County Comm'n, 535 F.2d 277, 281 (5th Cir. 1974).

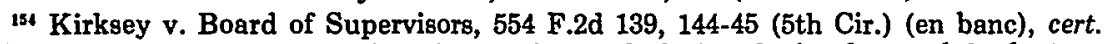
denied, 434 U.S. 968 (1977). Kirksey in part justified placing the burden on defendants to show that past discrimination has ended by making reference to school desegregation decisions. 554 F.2d at 145 n.12. The Supreme Court in Swann v. Charlotte-Mecklenburg Bd. of Educ., 402 U.S. 1, 26 (1971), held that "in a system with a history of segregation the need 
only past, but also future denial of access to the political process. The Fifth Circuit has also relieved plaintiffs of the burden of proving that economic and educational deprivation has significant political effect. The court will infer this causal connection. ${ }^{155}$

Participation in the political process does not include sham opportunities or rigged contests. Only where participation has a reasonable chance to build political influence does it satisfy the demands of the fourteenth amendment. In Turner $v$. McKeithen, ${ }^{156}$ for example, it was shown that blacks were consulted in the candidate slating process, but only "at a stage when the actual candidate selection ha[d] already occurred and the possibility for meaningful influence . . . [was] significantly diminished." 157 The core evil is the denial of political power; the insistence on proof of unequal opportunity to participate ensures that the analysis will take into account all methods of exercising that power.

\section{Affirmative Defenses}

If the plainiffs have established a prima facie case of significant ${ }^{158}$ voting dilution, defendants may raise the affirmative defense of legitimate governmental purpose, ${ }^{159}$ such as preservation of traditional voting boundaries, protection of incumbents, equalization of land area, or maintenance of longstanding at-large or multimember voting schemes. The cases do not specify, however, what degree of scrutiny is appropriate in evaluating these various governmental policies. Some lower courts, applying the two-tier analysis of such

for remedial criteria . . . warrants a presumption against schools that are substantially disproportionate in racial composition." A similar presumption can be applied to redistricting plans where a minority controls the outcome in a disproportionately small number of districts. Defendants cannot rebut proof of previous denial of access by the naked assertion that now and henceforth the electoral process is equally open to members of the plaintiff's group. But see Nevett v. Sides, 571 F.2d 209, 227 n.26 (5th Cir. 1978); Cousins v. City Council, 503 F.2d 912, 922-24 (7th Cir. 1974), cert. denied, 420 U.S. 992 (1975).

$1 \mathrm{ss}$ Id. at 145 .

150490 F.2d 191 (5th Cir. 1973).

157 Id. at 195.

iss Just as small deviations from population equality are tolerated without justification in state reapportionment cases, Reynolds v. Sims, 377 U.S. 533, 577 (1963) ("Mathematical exactness or precision is hardly a workable constitutional requirement."); Gaffney v. Cummings, 412 U.S. 735, 745 (1973) ("minor deviations from mathematical equality among state legislative districts are insufficient to make out a prima facie case of invidious discrimination under the Fourteenth Amendment."), insignificant dilutions of the voting power of groups will not give rise to a claim, see, e.g., Cousins v. City Council, 503 F.2d 912 (7th Cir. 1974), cert. denied, 420 U.S. 992 (1975).

is $C$. Gaffney v. Cummings, 412 U.S. 735, 736-52 (1973) (justifications for deviation from population equality). The point at which the burden shifts to the defendant depends on whether a showing of intent is held to be a part of the plaintiff's case. See Part IV infra. 
cases as San Antonio Independent School District v. Rodriguez, ${ }^{160}$ have applied only minimum scrutiny. ${ }^{161}$ The Seventh Circuit, for example, analyzed the language of the Supreme Court voting dilution cases and concluded that "the 'strict scrutiny' test has not been applied in racial gerrymandering cases." 162 It can be argued that, whether the voting dilution cases are viewed as an abridgement of the "fundamental" right to vote, ${ }^{163}$ or as discrimination against a "suspect class", ${ }^{164}$ policies that result in voting dilution must be strictly scrutinized to determine whether there is a compelling state interest to justify the challenged plan. As a practical proposition, however, most courts appear to have adopted a sliding scale approach: ${ }^{105}$ justification required varies inversely with the extent of the variation from equality of voting power, with the courts accepting virtually no policy as adequate justification for very large deviations. ${ }^{168}$

The strength of various affirmative defenses is thus determined largely by the particular factual situation and the degree of diminution of voting power involved. Some patterns do emerge from the cases, however. At-large election plans designed by an elected body, which arguably have the effect of avoiding destructive political fragmentation and forcing officials to consider the good of the wider community, are often upheld if they have been in effect for a long period of time. ${ }^{167}$ Similarly, the preservation of existing, traditional,

tw 411 U.S. 1 (1973).

tu Cousins v. City Council, 503 F.2d 912, 923 (7th Cir. 1974), cert. denied, 420 U.S. 992 (1975); Dunn v. Oklahoma, 343 F. Supp. 320, 330 (D. Okla. 1972). But see Reese v. Dallas County, 505 F.2d 879, 886-87 (5th Cir. 1974), rev'd on other grounds, 421 U.S. 477 (1975) (applying strict scrutiny).

I1: Cousins v. City Council, 503 F.2d 912, 923 (7th Cir. 1974), cert. denied, 420 U.S. 992 (1975), citing, inter alia, White v. Regester, 412 U.S. 755 (1973); Whitcomb v. Chavis, 403 U.S. 124 (1971); Kilgarlin v. Hill, 386 U.S. 120 (1967).

10 See Harper v. Virginia Bd. of Elections, 383 U.S. 663, 667 (1966); Reynolds v. Sims, 377 U.S. 533, 562 (1964); Yick Wo v. Hopkins, 118 U.S. 356, 370 (1886); L. TRIBE, supra note 6 , at $8 \& 16-7,16-10$.

I4 Korematsu v. United States, 323 U.S. 214, 216 (1944). See generally L. Trise, supra note 6 , at $\$ \$ 16-13$ to $16-29$.

1w Mr. Justice Marshall has suggested that the Court has applied a "spectrum of standards" depending on the importance of the interest asserted, the character of the classification, and the state interests in support of the classification. San Antonio Independent School Dist. v. Rodriguez, 411 U.S. 1, 98 (1973) (dissenting opinion). See generally Gunther, Foreword: In Search of Evolving Doctrine on a Changing Court: A Model for a Newer Equal Protection, 86 HARv. L. REv. 1 (1972); Karst, Foreword: Equal Citizenship Under the Fourteenth Amendment, 91 Harv. L. Rgv. 1 (1977).

I4 See Gaffney v. Cummings, 412 U.S. 735 (1973).

107 That a multimember plan has been in effect for a long period of time aids in rebutting the charge that it is a pretext for discrimination. See Whitcomb v. Chavis, 403 U.S. at 149; Black Voters v. McDonough, 665 F.2d 1, 4 (1st Cir. 1977); Dove v. Bumpers, 364 F. Supp. 
or convenient voting district boundaries has served to justify deviations from the ideal, ${ }^{168}$ partly because familiar boundaries are thought to promote efficient government by making it easier for voters to discover where they vote and who represents them. The equalization of land area and road mileage, on the other hand, is an example of a "legitimate planning objective" "169 that has frequently not withstood judicial scrutiny. ${ }^{170}$

\section{The InTENT Requirement}

A crucial, and as yet unresolved question is whether plaintiffs bringing a voting dilution claim must prove discriminatory intent. Neither Regester nor Zimmer addresses the issue of intent, and lower courts have incorporated inconsistent formulations of an intent requirement in their gerrymander decisions. In Cousins v. City Council, ${ }^{171}$ the Seventh Circuit painstakingly combed the record for evidence of a "purpose of diluting or minimizing the voting power" of plaintiff racial and ethnic groups. ${ }^{172}$ The Fifth Circuit cases, in contrast, have until recently allowed plaintiffs to prove either discriminatory intent or discriminatory effect. ${ }^{173}$

These two approaches to intent represent differing views of the source and rationale of the voting dilution cause of action. The approach adopted in Cousins reflects the view that gerrymander

407, 413 (E.D. Ark. 1973). But see Kendrick v. Walder, 527 F.2d 44 (7th Cir. 1975); Wallace v. House, 515 F.2d 619, 632 (5th Cir. 1975), vacated, 425 U.S. 947 (1976).

14 See, e.g., Mahan v. Howell, 410 U.S. 315 (1973); Abate v. Mundt, 403 U.S. 182 (1971); Panior v. Iberville Parish School Bd., 536 F.2d 101, 104 (5th Cir. 1976).

11" Howard v. Adams County Bd. of Supervisors, 453 F.2d 455, 456 (5th Cir.), cert. denied, 407 U.S. 925 (1972). See also Moore v. Leflore County Bd. of Election Comm'rs, 502 F.2d 621, 626 (5th Cir. 1974). But see Robinson v. Commissioners Court, 505 F.2d 674, 680 (5th Cir. 1974).

17 Kirksey v. Board of Supervisors, 554 F.2d 139 (5th Cir.) (en banc), cert. denied, 434 U.S. 968 (1977); Robinson v. Commissioners Court, 505 F.2d 674, 680 (5th Cir. 1974). But see Moore v. Leflore County Bd. of Election Comm'rs, 502 F.2d 621, 625 (5th Cir. 1974).

17466 F.2d 830 (7th Cir.), cert. denied, 409 U.S. 893 (1972).

172 Id. at 841. See also the later decision in Cousins, 503 F.2d 912, 916-20 (7th Cir. 1974), cert. denied, 420 U.S. 992 (1975); Stewart v. Waller, 404 F. Supp. 206, 213-15 (N.D. Miss. 1975); United States v. Democratic Executive Comm., 288 F. Supp. 943, 946-47 (M.D. Ala. 1968); Smith v. Paris, 257 F. Supp. 901, 904-05 (M.D. Ala. 1966), modified on other grounds, 386 F.2d 979 (5th Cir. 1967).

173 E.g., Panior v. Iberville Parish School Bd., 536 F.2d 101, 104-05 (5th Cir. 1976); Ferguson v. Winn Parish Police Jury, 528 F.2d 592, 597 (5th Cir. 1976); Wallace v. House, 515 F.2d 619, 622-23 (5th Cir. 1975), vacated on other grounds, 425 U.S. 947 (1976); Zimmer v. McKeithen, 485 F.2d 1297, 1304 (5th Cir. 1973), aff'd per curiam on other grounds sub nom. East Carroll Parish School Bd. v. Marshall, 424 U.S. 636 (1976); Howard v. Adams County Bd. of Supervisors, 453 F.2d 455, 457-58 (5th Cir.), cert. denied, 407 U.S. 925 (1972). These cases have applied the concept of discriminatory effect as a substantial impairment of political power. See text and note at note 112 supra. 
challenges are grounded on a racial discrimination theory, ${ }^{174}$ while the Fifth Circuit cases have relied on the Fortson dictum that plans which "designedly or otherwise . . . operate to minimize or cancel out the voting strength of racial or political elements of the voting population"175 are susceptible to constitutional challenge. This latter view of the role of intent, which the Supreme Court reemphasized in Burns $v$. Richardson, ${ }^{176}$ was construed by the Fifth Circuit as reducing intent to a sufficient, but not a necessary, element of the cause of action. In two recent cases, ${ }^{177}$ however, the Fifth Circuit doctrine has undergone a change. In response to the Supreme Court's decisions in Washington v. Davis ${ }^{178}$ and Village of Arlington Heights v. Metropolitan Housing Development Corp. ${ }^{178}$ insisting on proof of racially discriminatory intent in equal protection cases, the Fifth Circuit has held that "a showing of racially motivated discrimination is a necessary element in an equal protection voting dilution claim." 180

In Davis, the disproportionate impact of a personnel test on blacks was insufficient to render the test unconstitutional under the fourteenth amendment. The Court held that racially discriminatory intent must be proved. ${ }^{181}$ Similarly, in Arlington Heights, intent was held a necessary element in a challenge to allegedly discriminatory zoning practices. ${ }^{182}$ The reasoning in these two cases is broad and not easily confined: "[T] he invidious quality of a law claimed to be racially discriminatory must ultimately be traced to a racially discriminatory purpose." 183

The Fifth Circuit supported its application of Davis and Arlington Heights to voting dilution cases on two separate grounds. Judge Godbold, writing for the en banc majority in Kirksey v. Board of Supervisors, ${ }^{184}$ asserted that the intent standard adopted by the Supreme Court was fully consistent with the Court's earlier decisions in Chavis and Regester. According to the court, plaintiffs in

in See 466 F.2d at 841 . Significantly, the Cousins majority rejected the claim of dilution by a political group. Id. at 844-45.

173379 U.S. 433, 439 (1965) (emphasis added).

i7e 384 U.S. 73, 88, 89 (1966).

17 Nevett v. Sides, 571 F.2d 209 (5th Cir. 1978); Kirksey v. Board of Supervisors, 554

F.2d 139 (5th Cir.) (en banc), cert. denied, 434 U.S. 968 (1977).

178426 U.S. 229 (1976).

173429 U.S. 252 (1977).

100 Nevett v. Sides, 571 F.2d 209, 219 (5th Cir. 1978).

13426 U.S. 229,239 (1976).

162429 U.S. 252, 270-71 (1977).

100426 U.S. 229,240 (1976).

im 554 F.2d 139 (5th Cir.) (en banc), cert. denied, 434 U.S. 968 (1977). 
the former case lost because they had alleged only discriminatory effects, while in the latter case plaintiffs had established intent through the demonstration of denial of access. ${ }^{185}$ Kirksey thus viewed Davis and Arlington Heights as in no way suggesting that Regester was not "alive and well." ${ }^{188}$ In Nevett $v$. Sides, ${ }^{187}$ the Fifth Circuit found more direct support in the language of Davis. The Davis Court discussed with approval its earlier decision in Wright $v$. Rockefeller, ${ }^{188}$ in which the Court had denied plaintiffs' claim because of their failure to demonstrate either that the challenged districts were drawn along racial lines or were motivated by racial considerations. ${ }^{189}$ The Nevett court concluded that this "reaffirmation" of Wright "leaves no doubt that a showing of intent is a necesary element in a case alleging a racial gerrymander."190 Moreover, because the Arlington Heights Court categorized Wright as an "election districting" case, ${ }^{191}$ and because the Fifth Circuit regarded the racial gerrymander at issue in Wright as indistinguishable from the voting dilution cases, ${ }^{192}$ the Nevett court found the intent requirement applicable to all voting dilution claims.

Based on its conclusion that Regester had required a showing of intent, the Nevett court held that the criteria developed in Zimmer provide a sufficient basis for the inference of intent. ${ }^{193}$ The court explained how each of the Zimmer criteria speaks to intent: denial of voter registration or access to the slating process indicates that the minority's lack of influence is not adventitious, but intentional; ${ }^{194}$ unresponsiveness of officials resulting from impediments to minority political participation supports an inference of discriminatory purpose; 195 "tenuous" legislative policy suggests an impermissible underlying purpose; ${ }^{196}$ and past discrimination against a minority group suggests that maintenance of such discrimination underlies a putatively neutral districting scheme ${ }^{107}$ By equating a finding of dilution under Zimmer with satisfaction of the intent require-

18s Id. at 148 .

iu Id. n.17.

17 571 F.2d 209 (5th Cir. 1978).

14 376 U.S. 52 (1964).

i1" 426 U.S. at 240.

iv 571 F.2d at 218. Judge Tjoflat also agreed with Kirksey's assessment of Regester and Chavis. Id. at 219 n.13.

111429 U.S. at 265.

in 571 F.2d at 219.

iss Id. at 222-25.

is Id. at 223 .

iss Id. at 223 n.19.

16 Id. at 224.

in See id. at 222. 
ment of Davis, the court was able to support the result, while undermining the reasoning, of a series of prior Fifth Circuit voting dilution decisions. ${ }^{198}$ Since each of these cases found dilution under the Zimmer criteria, each necessarily established the essential element of intent. ${ }^{199}$ Thus, while the test for voting dilution is unchanged, the Fifth Circuit now views the ultimate issue addressed by the Zimmer test to be discriminatory intent, not the denial of access to the political process.

Satisfaction of the Fifth Circuit's current intent requirement is not limited to the inference of discriminatory intent in the enactment of a challenged districting scheme. If, as in Kirksey, the plan is facially neutral but carries forward a pattern of intentional discrimination, the Nevett majority would regard the necessary element of intent to be present. ${ }^{200}$ Similarly, the Fifth Circuit, in Bolden v. City of Mobile, ${ }^{201}$ held that legislative inaction that maintains an existing discriminatory districting scheme-even if the plan was neutral at its inception-provides the requisite intent. ${ }^{202}$ The Nevett court read Davis as supporting the conclusion that discriminatory impact need only be traced to some discriminatory intent. ${ }^{203}$ In both of the above situations, the court noted in Nevett, application of the Zimmer criteria is probative of intent.

Judge Wisdom, concurring specially in Nevett, rejected the majority's conclusion that Davis and Arlington Heights impose an intent requirement in voting dilution cases and objected to their reading of the voting dilution precedents. He found both arguments for the intent requirement unconvincing: Regester and Chavis did not require proof of discriminatory intent, and Davis and Arlington Heights did not advert to, and thus did not modify, the voting dilution cases. ${ }^{204}$ At the heart of Judge Wisdom's argument lay his contention that voting rights cases are distinguishable from all other equal protection cases. ${ }^{203}$ Returning to the source of the voting dilution doctrine, Reynolds $v$. Sims, he noted that restriction of the right to vote, which may be challenged without showing intent,

19s See note 173 supra and cases cited at 571 F.2d 209, 225 (5th Cir. 1978).

11" $571 \mathrm{~F} .2 \mathrm{~d}$ at 225.

$200 \mathrm{Id}$. at 222.

271 F.2d 238 (5th Cir.), prob. juris. noted, 47 U.S.L.W. 3221 (U.S. Oct. 2, 1978) (No. 77-1844).

202 Id. at 246.

20071 F.2d at $219-20$ n.13.

204 Id, at 232.

200 Id. at 233. He based this distinction on the notion that the right to vote is "a fundamental political right, because [it ig] preservative of all rights." Id. (quoting Yick Wo v. Hopkins, 118 U.S. 356, 370 (1886)). 
results from qualitative as well as quantitative dilution of citizens' votes. Because he regarded the voting dilution claim as a distinct constitutional doctrine, Judge Wisdom had no problem severing the Davis Court's approval of the intent requirement in Wright $v$. Rockefeller, which, although occurring in the context of voting rights, was analyzed as a racial discrimination claim, from the voting rights cases brought under a voting dilution theory. ${ }^{208}$

Judge Wisdom was concerned that the shift in theory from a requirement of proof of invidious effects to proof of intent would have the practical effect of significantly impeding the ability of plaintiffs to succeed in voting dilution cases, and would, in fact, contract the scope of the cause of action. That the cause of action itself might be limited by the intent requirement follows from Judge Wisdom's reading of Davis. Where discriminatory purpose is adduced only on the basis of a failure to affirmatively cure past discrimination-a situation in which the Zimmer criteria have been found satisfied ${ }^{207}$ and which the majority would find implies intent-a finding of intent would be "inconsistent" with Davis. ${ }^{208}$ Judge Wisdom warned that the process of inferring intent from a "laundry list" of factors would cause voting dilution cases to turn on judges' attitudes toward the "American brand of Federalism." He therefore concluded:

The safe and sure test for the constitutionality of a voting plan is proof of invidious effects, such as the failure to give due weight to votes of members of a minority group. When there is clear proof of this effect, I disapprove of resorting to a douser to divine whether under an "aggregate" of surface factors there is an unconstitutional legislative motive. ${ }^{210}$

If, as the Nevett majority suggests, a finding of dilution under the Zimmer criteria necessarily supports the inference of improper intent, the debate between the majority and Judge Wisdom would be largely academic. It appears, however, that the shift in theory will in fact result in different contours for the substantive law of voting dilution.

Judge Wisdom is probably correct in his assertion that in those cases where intent must be inferred, judges may be less willing to

\footnotetext{
24571 F.2d at 236.

2m See text and notes at notes 198-99 supra.

20 571 F.2d 209, 233 (5th Cir. 1978).

2m Id.

210 Id. at 234.
} 
hold that the Zimmer test has been satisfied.211 More significantly, the Nevett majority's conclusion that intent may be found in the failure to remedy some past intentional discrimination may be, as Judge Wisdom asserted, incompatible with Davis and Arlington Heights. The majority's position suggests that the requisite intent need not be found in official action at all, so long as the discriminatory effect is attributable to the discriminatory intent of someone-perhaps the community at large. Such intent might have been found in both Davis and Arlington Heights, ${ }^{212}$ yet in neither case did the Court suggest that the requisite intent could be so remote. If the source of the constitutional violation is the plan itself, then the plan must be shown to be conceived or maintained with improper purpose. Under this formulation of the intent requirement, some cases otherwise satisfying Zimmer would fail to demonstrate the requisite intent. 213 Thus, an intent requirement may well have the effect of narrowing the scope of the voting dilution cause of action.

It is possible that Regester, as the Nevett majority asserted, ${ }^{214}$ did include an intent requirement. If so, the use of the Zimmer criteria to establish intent, applied within the bounds of Davis and Arlington Heights, would reconcile the voting dilution claim with current equal protection doctrine. ${ }^{215}$ 'The statement of the plaintiffs'

211 Although Judge Wisdom's concern about federal judges' deference to the states, id. at 233 , is not a persuasive argument against an intent requirement, the observation that judges will hesitate to impose the label of intentional discrimination on state legislatures is a valid one.

212 The Court could have traced the disproportionate impact of the race-neutral test for police officers to deliberate discrimination in education and the economy, which contributed to the inability of many blacks to pass the test. Similarly, the Court could have found the disproportionate impact of the race-neutral zoning ordinance in the racial discrimination that contributes to the relative poverty of blacks.

2ss See, e.g., Bolden v. City of Mobile, 571 F.2d 238 (5th Cir.), prob. juris. noted, 47 U.S.L.W. 3221 (U.S. Oct. 2, 1978) (No. 77-1844). In Bolden, the court found that because there was evidence of pervasive past discrimination and because the Zimmer criteria were satisfied, maintenance of an otherwise race-neutral plan exhibited the requisite discriminatory intent. Id. at 244-46. The court cited Kirksey for the proposition that a plan is impermissible if it perpetuates past discrimination. Id. at 246. The court thus appears to have confused the standard of review for a court-ordered plan (Kirksey) with that for challenges to legislative plans (Bolden). See note 229 infra.

214571 F.2d 209, 219-20 n.13 (5th Cir. 1978).

215 If an intent requirement is to be applied to voting dilution cases, the Nevett/Zimmer test is not the only conceivable approach. It is established that racial motivation need not be the sole, or even the primary reason for the districting plan, Arlington Heights, 429 U.S. at 265; discriminatory purpose need only be one motivating factor. Id. at 265-66. Courts have taken at least two other positions on what form of proof suffices to establish intent. The first, and strictest, of these alternatives focuses on the motive of the legislature. This approach, taken by the court in Cousins v. City Council, 466 F.2d 830, 834-37 (7th Cir.), cert. denied, 409 U.S. 893 (1972), emphasizes direct evidence of the subjective purposes of individual legislators. Such an evidentiary standard, which can be met only in the most blatant cases, 
case in Regester, however, focuses on proof of discriminatory effects. "The plaintiffs' burden is to produce evidence to support findings that the political process leading to nomination and election were not equally open to participation by the group in question . . . ."216 No intent requirement is appended to this summary of plaintiffs' burden of proof, and the Court's decision appears to have relied on evidence of intent only insofar as it served to establish discriminatory impact. ${ }^{217}$ "The District Court . . . conclude[d] that the multimember districts, as designed and operated in Bexar County, invidiously excluded Mexican-Americans from effective participation in political life ....."218

Imposing an intent requirement on voting dilution challenges to gerrymanders would misconstrue the nature of the right protected in Regester. Intent is relevant where a governmental policy is alleged to impact differentially on a suspect class, not where the legislature is under an obligation to allocate a right or benefit equally to all citizens. ${ }^{219}$ The distinction can be explained as one between the "right to equal treatment" and the "right to treatment as an equal". ${ }^{220}$ The right to equal treatment applies only to "a limited set of interests-like voting-and demands that every person have the same access to these interests as every other person"; ${ }^{221}$ the right to treatment as an equal applies in all cases and reflects the government's general obligation to treat its citizens with "equal concern

is more restrictive than that envisioned by the Court in Arlington Heights. It is unlikely future courts would limit their inquiry to direct evidence. The second approach, employing the torts principle that a person intends the natural and foreseeable consequences of his actions, was suggested by Justice Stevens's concurrence in Davis. 426 U.S. at 253. See also Brown v. Moore, 428 F. Supp. 1123, 1136-39 (S.D. Ala. 1976). Under this approach, plaintiffs would have the relatively light burden of proving that the challenged plan could reasonably be predicted to have the effect of diminishing the voting strength of the plaintiff group. Though analytically appealing, this approach probably would not satisfy the Arlington Heights Court, which said that "impact of the official action" would support an inference of intent only in the rare cases where the pattern is "stark." 429 U.S. at 266.

211412 U.S. at 766.

217 But see L. TrIBE, supra note 6, at $\$ 16-18$, at $1028-29$ (Regester suggests that both effects and intent must be shown).

211 412 U.S. at 769.

210 See generally L. TrIBE, supra note 6, at \& 16-7.

220 The distinction is drawn by Ronald Dworkin, R. Dworkin, Taking Rights Seriousty 227 (1977); Dworkin, Social Sciences and Constitutional Rights-The Consequences of Uncertainty, 6 J.L. \& EDvc. 3, 10-11 (1977), and adopted by Laurence Tribe, supra note 6, at $\$ 16-1$, at $992-93$.

221 L. TRIBE, supra note 6, at $\$ 16-1$, at 992-93. Professor Tribe, drawing on Dworkin, notes that the right to equal treatment cannot apply to all interests since "any such universal demand for sameness would prevent government from discriminating in the public interest." Id. at 993. 
and respect."222 When equal protection cases are categorized in this way, it becomes clearer that a single intent standard is inappropriate. The right to equal treatment is defined in terms of the effect on the individual of governmental action. The equal concern and respect inherent in the right to treatment as an equal, on the other hand, necessarily involves the attitude and motive underlying legislative action: discriminatory impact may be relevant evidence that the government has failed to treat all citizens fairly, but intent is the essential element of the claim.

Thus, Davis and Arlington Heights can and should be distinguished from the voting dilution cause of action, which is grounded in the fundamental right to vote. In Reynolds the Court did not hold that each citizen has the right to be protected from intentional malapportionment, but that he has a substantive right to districts drawn within certain population variances. ${ }^{223}$ Similarly, granting some voters greater power because of their political affiliation should never be permissible. Judge Wisdom correctly included voting dilution cases within a category distinct from other equal protection cases. The rationale of the voting dilution claim has been demonstrated to derive from (and to be qualitatively indistinguishable from) the theory of the one man, one vote mandate of Reynolds. ${ }^{22 t}$ Legislative action challenged on the ground that it has a greater negative impact on one race than another must, after Davis, generally be shown to be intentinally discriminatory to be overturned; a legislative action allocating the political power incident to the right to vote need only be shown to have allocated that power unequally. 225

The question remains whether the Court intended in Davis and

22 Dworkin, supra note 220 , at 10.

22 See text and notes at notes 53-54 supra. By contrast, where the legislature is engaged in making an arguably permissible classification among citizens-as, for example, by zoning or by setting qualifications for employment-the plaintiff must challenge the classification as being racially motivated.

224 See text and notes at notes 53-66 supra.

23 But see Ely, Legislative and Administrative Motivation in Constitutional Law, 79 YALE L.J. 1205 (1970). Professor Ely argues that political districting falls within the class of governmental distinctions which are necessarily arbitrary. Merely because one person is disadvantaged relative to another by the choice of district boundaries does not, in his view, subject the plan to constitutional scrutiny. Rather, the legislature is constitutionally prohibited from employing improper criteria in drawing the lines. To trigger scrutiny, therefore, it is necessary to prove that the legislature drew up the plan with discriminatory intent. His analysis preceded the decisions in Chavis, Regester, Davis, and Arlington Heights. See id. at 1230-37, 1249-66. An analogy might be drawn to school desegregation cases: mere racial disproportion, de facto, is not sufficient to require desegregation action; only where de jure segregation is found to have existed does the plaintiff win a desegregation case. See id. at 1289-98. 
Arlington Heights to alter the requirements of the plaintiff's case. The answer depends on whether the Court's endorsement of Wright $v$. Rockefeller in both opinions can be regarded as speaking to the voting dilution cause of action. The Nevett majority insisted that it can be, since they saw no distinction between the racial gerrymander alleged in Wright and the districting schemes challenged by the voting dilution cases. The problem with this reasoning is that although the contexts may be analogous, the theory on which Wright was brought is distinguishable from the voting dilution theory as it has subsequently developed. Plaintiffs in Wright brought the case on the ground that they were the victims of an intentional, racially segregative districting scheme. ${ }^{226}$ Since the Court, at the time it decided Wright, had not yet upheld a voting dilution claim (or even recognized the possibility of such a claim in the single-member district context), it would have been incongruous to go beyond the plaintiffs' theory in that case to do so. A more reasonable explanation of Davis's citation of Wright is that the Court merely sought to establish a broad range of contexts in which the Court had previously required a showing of intent to sustain racial discrimination claims alleging violation of the right to treatment as an equal. ${ }^{227}$

\section{Court-Ordered Remedies}

When a court strikes down an existing state districting scheme, it will, "whenever practicable," allow the legislature to redraw districting boundaries rather than impose its own plan. ${ }^{228}$ If, because of legislative inaction, a court is compelled to devise a districting plan to remedy voting dilution, ${ }^{229}$ that plan is held to a higher

$22 x$ See text and notes at notes 67-77 supra. The Court noted that plaintiffs had argued before the District Court that "the only province of the Court in this area is to determine whether or not these districts have been created with racial considerations in mind." 376 U.S. at 54. The Court expressly addressed only the issue, stated in appellants' jurisdictional statement to the Court, "[w]hether appellants sustained their burden of proving that [the statute] . . . segregates eligible voters by race and place of origin." Id. at 56.

227 See 426 U.S. at 238-41.

22 Wise v. Lipscomb, 98 S. Ct. 2493, 2497 (1978). This follows from the Court's oftrepeated statement that redistricting and reapportionment are legislative tasks. See id. and cases cited therein.

20 The precise scope of plans regarded as "court-ordered" has apparently changed following the Court's decision in Wise. The Court distinguished plans submitted to and "adopted" by a court from those adopted by a legislative body and subsequently submitted to and approved by the court. Id. at 2499-500. An example of the first case, said the Court, was the plan reviewed in East Carroll Parish School Bd. v. Marshall, 424 U.S. 636 (1976), in which the legislative bodies submitting the plans "did not purport to reapportion themselves and, furthermore, could not even legally do so under federal law." Wise v. Lipscomb, $98 \mathrm{~S}$. Ct. 2493, 2500 (1978). Apparently any plan adopted by a legislative body and "effective as 
standard than a corresponding legislative enactment. ${ }^{230}$ A courtordered plan must affirmatively remedy the denial of access that was found in the existing districting plan; a plan that does not ensure equality of voting power will be ruled "an abuse of [the court's] discretion." 231 The duty of the court should be distinguished from that in racial discrimination cases in which the remedies need only eliminate the effects of past discrimination and bar like discrimination in the future. ${ }^{232}$ The right to participate in the electoral process, like the right to voting district population equality is a continuing affirmative right to a fair share of political influence. Thus, while there is no continuing right to integrated schools recognized in school desegregation cases, ${ }^{233}$ voting districts must be drawn to protect, to the fullest extent possible, the future ability of a group to exert political power.

United Jewish Organizations $v$. Carey ${ }^{234}$ cast doubt on the argument that legislatures or courts must be race-neutral in the drawing of election districts. ${ }^{235}$ Indeed, to create an effective remedy for discrimination in the distribution of voting power, it may be impossible for the courts to ignore the racial composition of districts. This does not imply, however, that the courts must apply "reverse discrimination" to correct past abuses: they need only guarantee the minority its fair share of political power. ${ }^{238}$ Although some misgivings are still

law"- even though ordered by a federal court-is to be judged as a legislative rather than a court-ordered plan. After Wise, it is unclear whether the plan in Kirksey, drawn by the county board of supervisors and "approved and adopted" by the district court, 554 F.2d at 141-42, was correctly treated by the Fifth Circuit as a court-ordered plan.

200 Chapman v. Meier, 420 U.S. 1, 18-19 (1975); Kirksey v. Board of Supervisors, 554 F.2d 139, 151-52 (5th Cir.) (en banc), cert. denied, 434 U.S. 968 (1977).

231 Kirksey, 554 F.2d at 152. For example, barring exceptional circumstances, a court may not employ multimember districts in its plan. Connor v. Finch, 431 U.S. 407 (1977); Chapman v. Meier, 420 U.S. 1, 19 (1975). See Wallace v. House, 538 F.2d 1138, 1140-41 (5th Cir.), vacated, 425 U.S. 947 (1976).

222 See Milliken v. Bradley, 433 U.S. 267 (1977); Pasadena City Bd. of Educ. v. Spangler, 427 U.S. 424 (1976); Swann v. Charlotte-Mecklenburg Bd. of Educ., 402 U.S. 1 (1971); Green v. County School Bd., 391 U.S. 430 (1968).

235 See Milliken v. Bradley, 418 U.S. 717 (1974); Dixon, The Supreme Court and Equality: Legislative Classification, Desegregation, and Reverse Discrimination, 62 CoRnerL L. REv. 494, 541-44 (1977).

23430 U.S. 144 (1977).

235 Id. (majority opinion); cf. Swann v. Charlotte-Mecklenburg Bd. of Educ., 402 U.S. 1 (1971) (school desegregation). See also 430 U.S. at 172 n.2 (Brennan, J., concurring); Kirksey v. Board of Supervisors, 554 F.2d 139, 151-52 (5th Cir.) (en banc), cert. denied, 434 U.S. 968 (1977).

24 United Jewish Organizations concerned a plan designed to create black legislative seats commensurate with, not exceeding, black population. Cf. Gaffney v. Cummings, 412 U.S. 735 (1973) (districts designed to allocate legislative power fairly between Republicans and Democrats).

The Fifth Circuit has recently taken the position that although proportional representation of racial groups is a permissible goal of legislative plans, it is an improper basis for court- 
expressed about the possible ill effects of apparent preferential treatment, ${ }^{237}$ these concerns might be allayed if the courts indicated more clearly that the group for which a remedy is being provided is a political group first and an ethnic group second, and if compensatory districting were available to all disadvantaged political groups.

In addition to the stricter substantive standard imposed on court-ordered plans, the courts face difficult practical problems in fashioning adequate remedies for voting dilution. A group that is highly diffuse may be unable to benefit from any redrawing of district lines: if the only way to ensure political influence for such a minority group would be to construct exceedingly ungainly districts, the court would be unable to design a remedy. Some commentators have suggested that gerrymanders would be discouraged if courts required that districts always be drawn compactly. ${ }^{238}$ There is no assurance, however, that compact districts are always more fair than unwieldy ones. 239 Normally one thinks of a gerrymander as the use of stretched-out boundaries. In such cases, compactness may provide an adequate standard for designing a remedy. In other cases, the use of highly compact districts may be the most effective way to shut out a minority from equal participation. A strict compactness requirement would leave groups that could benefit from

ordered reapportionment plans. Marshall v. Edwards, 582 F.2d 927 (5th Cir. 1978). The Fifth Circuit has held that "safe" seats for minority groups are not required in a plan to remedy voting dilution. E.g., United States v. Board of Supervisors, 571 F.2d 951, 955 (5th Cir. 1978). The court recognizes, however, that judicial consideration of race in formulating a remedial plan is not inappropriate. Marshall v. Edwards, 582 F.2d at 936. In drawing plans to remedy voting dilution, district judges must "be mindful of the impact of the proposed plans on different racial groups."' Id. at 937. This requires analysis of the results of any court-ordered plan in terms of the voting power of minority groups. Id. A tension between this requirement and the prohibition of the use of proportional representation is bound to result in cases in which voting blocs are polarized along racial lines. Remedies in such cases must approximate proportional representation in order to be effective; such remedies will evidently be permissible as long as this goal is not made explicit. Cf. Regents of Univ. of Calif. v. Bakke, $98 \mathrm{~S}$. Ct. 2733 (1978) (race may be one factor in making medical school admissions decisions).

277 See, e.g., United Jewrish Organizations v. Carey, 430 U.S. at 171-72 (Brennan, J., concurring in part). Justice Brennan suggests that "benign" racial districting may "disguise a policy that perpetuates disadvantageous treatment of the plan's supposed beneficiaries," or may further stigmatize racial groups, $i d$. at 173-74, or may be viewed as unjust by those who are disadvantaged by preferences for another group. Id. at 174-75.

${ }^{238}$ See Schwartzburg, Reapportionment, Gerrymanders, and the Notion of "Compactness," 50 MinN. L. REv. 443 (1966); Comment, Political Gerrymandering: A Statutory Compactness Standard as an Antidote for Judicial Impotence, 41 U. CHI. L. Rkv. 398 (1974).

233 See Baker, Gerrymandering: Privileged Sanctuary or Next Judicial Target, in ReApportionment IN THE 1970's at 138 (N. Polsby ed. 1971) (demonstrating how a more compactly drawn district was more partisan in favor of the majority party than the former plan). 
slightly stretching out districting lines remediless. ${ }^{240}$

A compactness standard, even if appropriate, would not tell a court where to draw the districting lines. Several different plans, all using compact districts, can be designed for an area, but with very different political consequences. The "higher standard" required of courts in designing remedies surely does not always require courts to choose the "most compact" plan; rather, it requires the court to design the fairest possible plan. The court may have to decide between two or more feasible, compact district schemes; more than one court has noted that there is no agreement on "whether the political interests of a minority group are best maximized by an overwhelming majority in a single district, bare majorities in more than one district or a substantial proportion of the voters in a number of districts." ${ }^{411}$ The Supreme Court, in its preference for single over multimember districts in court-ordered plans, has made a judgment that a group is better off if it can elect one or more of its own members. This preference can be justified on the theory that a group can be more easily ignored when it has no spokesmen in the elected body: its political influence, if any, is a step removed from the decision-making process of the elected officials.

Where a multimember districting scheme is already in effect, certain changes in the electoral machinery might be less disruptive than the substitution of single-member districts, yet equally effective in increasing minority political power. If, for example, voters were permitted to vote for less than a full slate of candidates, parties that ran less than a full slate would have a greater chance of getting elected. Going a step further, a court might call for cumulative voting. ${ }^{242}$ Permitting voters to cast all their votes for a single candidate virtually assures minority representation, regardless of how diffuse the minority is. Thus far, however, courts have confined their remedial activities to redrawing lines-perhaps because it is a task to which they have grown accustomed, and perhaps because thus far the groups that have brought dilution claims have lived sufficiently close together that redrawing lines will generally secure them greater electoral influence.

For groups that comprise a very small percentage of the population, the only possible remedy might be to increase the number of

${ }^{310}$ For example, the minority party was able to achieve proportional representation through the use of districts with slightly cumbersome shapes, in a plan approved by the Supreme Court. Gaffney v. Cummings, 412 U.S. 735 (1973).

24 Turner v. McKeithen, 490 F.2d 191, 197, n. 24 (5th Cir. 1973).

$2 \sqrt{2}$ See ILL. Const. art. 4 \$ 7; Blair, The Case for Cumulative Voting in Illinois, $47 \mathrm{Nw}$. U.L. REv. 344 (1952); Note, Ghetto Voting and At-Large Elections: A Subtle Infringement Upon Minority Rights, supra note 19, at 1010. 
representatives in the legislature. Such a remedy would also be beyond the court's power to implement, for a court has no standards to guide it in deciding on the optimal number of representatives. ${ }^{243}$ Courts are not required to increase the size of the legislature until every interest group, no matter how minute, is represented. ${ }^{244}$

\section{Conclusion}

Gerrymandering is unconstitutional when it curtails voters' "opportunity to participate in the political processes." Although the rule is easily stated, the elements and scope of the voting dilution cause of action remain unsettled. It is clear only that this "opportunity" implies something more than a mere right to go to the polls, but less than a right to be represented by a member of one's political group. This comment has sought to demonstrate that the individual's right to participate is best evaluated in terms of the power of political groups. This protection of group political influence is derived from the "one person, one vote" rule of Reynolds $v$. Sims.

Confusion over exactly which groups are protected against dilution of their political power has resulted from a failure to distinguish the voting dilution cause of action from that class of cases brought on a racial discrimination theory. The voting dilution claim, properly viewed as founded on the nonracial "political influence" theory, should be available to any discrete political group. In addition, voting dilution challenges, unlike racial discrimination cases, should not be held to include an intent requirement. Broader recognition of the voting dilution claim does not unduly restrict the freedom of legislatures to design districting plans: it is possible to protect the right of a group to its fair share of political influence, while allowing for a wide variety of election outcomes. Nor will a broad application of the cause of action impose an onerous burden on the courts. Courts will be required to fashion remedies only in those cases where plaintiffs have met their difficult burden of proof and where a remedial districting plan can be practically designed to protect the interests of the group.

Joseph C. Markowitz

213 The Supreme Court found it beyond the scope of the district court's remedial powers to dramatically reduce the number of representatives to a state legislature. Sirty-Seventh Minnesota State Senate v. Beens, 406 U.S. 187 (1972). Minor variations in the number of representatives would be permissible, though, in a court-ordered plan. See id. at 198-99.

24 See Vollin v. Kimbel, 519 F.2d 790 (4th Cir.), cert. denied, 423 U.S. 936 (1975). 